\title{
Migrants at Sea: A Duty of Plural States to Protect (Extraterritorially)?
}

\author{
Vassilis P. Tzevelekos \\ Senior Lecturer in Law, University of Liverpool School of Law \\ and Social Justice, Liverpool, U K \\ Elena Katselli Proukaki \\ Senior Lecturer in Law, Newcastle University Law School, Newcastle, UK
}

\begin{abstract}
Although migration is a transnational phenomenon involving a plurality of states, the state of departure is often unwilling/unable to offer protection. Receiving/transit states can refrain from engaging with the problem until migrants have already entered their territory. With high seas, this can result in the deaths of people taking the risk of travelling to a new place. The article argues that states have a duty to offer (some) protection even when migrants are not in their territory, based on human rights' positive effect and the principle of due diligence. Because of the transnational nature of migration, all involved states have the responsibility to offer protection. This may lead to concurrent state liability for failure to protect. The duty to protect may extend to the high seas, even when the traditional links for the establishment of jurisdiction are absent. The duty is not unlimited, it needs to prevail over other considerations.
\end{abstract}

\section{Keywords}

human rights - extraterritoriality - migration - refugee protection - duty to protect due diligence - concurrent state responsibility - high seas

* The authors are thankful to Dr Daithi Mac Sithigh, Dr Antal Berkes, Dr Dimitrios Kagiaros and to the anonymous reviewer(s) for their helpful comments. The usual disclaimer applies.

(C) VASSILIS P. TZEVELEKOS AND ELENA KATSELLI PROUKAKI, 2017 | DOI 10.1163/15718107-08604003 


\section{Introduction}

This article is our reaction to the ongoing mass flows of migrants with particular focus on the tragic drownings of people and the plight of thousands, including women and young children, who are stranded at sea in unsuitable boats in the Mediterranean and elsewhere. ${ }^{1}$ With over 9,00o human lives lost and missing in the Mediterranean Sea since 2015, ${ }^{2}$ it is hardly surprising that it is imperative to consider how international human rights law responds to this challenge. ${ }^{3}$ On 18 April 2015 alone, almost 800 lives were lost in a single incident when a boat capsized 120 miles off the coast of the Italian island of Lampedusa. ${ }^{4}$ At the same time, thousands of persecuted Rohingya Muslims fleeing Myanmar as well as economic migrants from Bangladesh continue on a daily basis to be stranded at sea off the coast of Thailand, Malaysia and Indonesia. Not only are states reluctant to participate in search and rescue operations, ${ }^{5}$ they also often push boats carrying migrants away from their jurisdiction. ${ }^{6}$ Whilst

1 The picture of Aylan Kurdi (or Shenu), a three-year Syrian boy who was found dead on 2 September 2015 on the shore of Turkey, having drowned along with his mother and brother in their efforts to get from Turkey to the Greek Island of Kos, has caused international outrage. 'With Increasing Child Deaths at Sea, Iом and un Partner Agencies Urge Greater Protection for Migrants and Refugees', International Organisation for Migration, <http://www.iom.int/ news/increasing-child-deaths-sea-iom-and-un-partner-agencies-urge-greater-protection -migrants-and>, visited on 19 February 2016.

2 'Mediterranean: Dead and Missing at Sea (January 2015-31 January 2017)', United Nations High Commissioner for Refugees, <http://data2.unhcr.org/en/situations/mediterranean>, visited on 19 February 2017.

3 Ibid.

4 P. Kingsley, A. Bonomolo and S. Kirchgaessner, '70o migrants feared dead in Mediterranean shipwreck', The Guardian (19 April 2015), <http://www.theguardian.com/world/2015/ apr/19/70o-migrants-feared-dead-mediterranean-shipwreck-worst-yet $>$, visited on 19 February 2016.

5 See for instance the UK's decision to withdraw from search and rescue operations in October 2014 on the ground that such operations amounted to 'pull factors' that encouraged more migrants to undertake the unsafe journey. UK Foreign and Commonwealth Secretary Baroness Anelay, HL Deb, 15 October 2014, Col. wA41. For criticism of this policy see D. Hodges, 'Drown an immigrant to save an immigrant: why is the Government borrowing policy from the BNP?', The Telegraph (28 October 2014).

6 'Bangladesh PM says illegal migrants taint national image', ввс News (24 May 2015), <http:// www.bbc.co.uk/news/world-asia-32867221>, visited on 19 February 2016. See also the case law we examine below (Section 3), and especially the us policy in relation to flows from Haitian migrants in the 1980 s and 1990 s discussed by I. Mann, 'Dialectic of Transnationalism: 
clearly failing to take action for saving human lives constitutes, in the words of Peter Sutherland, the Special Representative of the Secretary-General for International Migration, a "moral failure", 7 this study goes further to argue that such failure is incompatible with established norms of positive international law. Contrary to a restrictive understanding of human rights obligations, we contend that states have a legal duty under international (human rights) law to search, rescue and, more generally, protect people who take the risk of travelling to a new land in quest of safety and dignity. This duty may also extend extraterritorially, at sea, but also before migrants reach the sea and emanates from a variety of legal bases in human rights law and in the law of the sea, read in the light of the principle of due diligence.

At the rise of the $21^{\text {st }}$ century, the suffering that results from armed conflict, human rights abuses, inequality and poverty in many parts of the world is not only continuing but it is also growing. Notably, however, "[t]he impact of global poverty and conflict do not end at national frontiers". ${ }^{8}$ They often result in the mass flow of migrants currently witnessed. Despite the fact that we live in an increasingly globalised, inter-connected and inter-dependent world, the borders are in many instances sharply closed for hundreds of thousands of people. This often forces them to go underground, risking exploitation by criminal gangs, including migrant smugglers and human traffickers. ${ }^{9}$ Whilst the continuing flows of migration - regular or irregular - place financial pressure and social strain on receiving states, ${ }^{10}$ migration presents significant humanitarian, as well as legal challenges. This is why it is necessary that migration, as well as maritime and land border controls be approached as an international

Unauthorized Migration and Human Rights, 1993-2013', 54 Harvard International Law Journal (2013) pp. 315-392, at 327-332 and 356-357.

7 'Refugees/Migrants Emergency Response - Mediterranean', European Data Portal, <http:// data.unhcr.org/mediterranean/regional.php\#_ga=1.77665105.415510178.1458064663> 6, visited on 19 February 2016.

'Communication from the Commission to the European Parliament, the Council, the European Economic and Social Committee and the Committee of the Regions: A European Agenda on Migration', Brussels, 13 May 2015 СОм (2015) 240 final, 2.

9 See interview of Chief Executive of the Refugee Council, M. Wren in 'UK opposes future migrant rescues in Mediterranean', вBC News (28 October 2014), <http://www.bbc.co.uk/ news/uk-29799473>, visited on 19 February 2016. See also infra note 71, as well as UNSC Res. 2240 (9 October 2015) UN Doc. S/RES/2240, preamble, which links casualties with "the exploitation and misinformation by transnational criminal organisations which facilitated the illegal smuggling of migrants ... for personal gain ...".

10 The existing tensions between immigration and economy are aptly captured in the UK House of Commons debates: R Harris, HC Deb, 13 October 2015, Col. 226. 
problem that ought to be addressed through collective action and co-operation in the framework of human rights and international law more generally. As Goodwin-Gill highlights, "[m]igrants, refugees and asylum seekers at sea are not just flotsam and jetsam, adrift and open to control and dispersal by whomever finds them". ${ }^{11}$ Whilst migration raises important legal questions concerning the right of states to take measures to prevent migrants from accessing their land and the lawfulness of the means through which states may "seal" their borders, ${ }^{12}$ these fall outside the scope of our analysis here, which specifically concerns the duty of (multiple) states to protect human life, even beyond their borders, especially on the high seas, and the limits of that duty.

In that respect, our study makes three main points that can be summarised as follows. First, migration, as a transnational phenomenon, may implicate the responsibility, concurrently, of multiple states for failure to exercise their duty to protect migrants in the context under consideration. Secondly, the duty to protect may extend extraterritorially, to the high seas, even when a state is not linked with a situation calling for protection through the traditional links (beyond territory) establishing jurisdiction, such as nationality, for instance. And, third, such duty is not absolute; it must be weighed against the significance of the rights/interests at stake.

The structure of this study follows the order of these three arguments. Before that, Section 1 briefly explains what the main legal "tools" are that are employed in the discussion that follows, and, mainly, delimits the article's area of analysis. For that purpose, it explains why the focus in this study is on human rights law and how that regime interacts with other rules and areas of international law and, in particular, with the law of the sea. Preliminary analysis in Section 1 prepares the ground for the article's main arguments. Starting with the first argument, Section 2 tackles the question of who owes protection and explains that a plurality of states are expected to offer protection simultaneously; this implies that these states are called to exercise parallel jurisdiction, as a consequence of which they may end up being concurrently liable. The transnational nature of migration justifies these conclusions and explains why jurisdiction

11 G. Goodwin-Gill, 'The Right to Seek Asylum: Interception at Sea and the Principle of NonRefoulement', 23 International Journal of Refugee Law (2011) p. 447; see also supra note 7 and infra note 171.

12 From its side, the UN Security Council stresses the obligation of states to protect migrants "including when implementing their specific migration and border security policies". unsc Res. 2240, supra note 9. See also the critique by T. Gammeltoft-Hansen and J.C. Hathaway, 'Non-Refoulement in a World of Cooperative Deterrence', 53 Columbia Journal of Transnational Law (2015) pp. 235-284. 
for protective purposes has an extraterritorial reach. Extraterritoriality is further discussed in Section 3, which raises the question of where protection is owed. That section of the article discusses non-refoulement ${ }^{13}$ as a means to comply with the duty to protect human life on the (high) seas, but also considers the scenario of absence of legal nexuses that could establish the jurisdiction of a state to protect, making the argument that, beyond the traditional legal nexuses, such as territory and nationality, effectiveness has the same effect and activates the duty to protect (for instance, in the context at discussion, the duty to rescue). As a result, states are legally expected to protect human life outside their territorial waters. In Section 4, the article discusses the limits of the right to protect (extraterritorially). Section 5 concludes the study.

\section{Delimiting Analysis: Due Diligence, the Positive Effect of Human Rights and the Inter-Relationship between Human Rights Law and Law of the Sea}

The article's main scope and the humble contribution it aspires to make are limited to the three aforementioned points, namely the existence of a plurality of states that are concurrently expected to act in a protective manner, the extraterritorial reach of the duty to protect, and its limits. The concept of protection is the key common element in respect to these three points. As such, protection corresponds to one of the three dimensions/effects human rights develop (the other two being respect and fulfilment) ${ }^{14}$ and is associated in international law with the broader concept of due diligence, ${ }^{15}$ which requires

13 See Section 1 of the study and infra note 43.

14 On the triptych respect-protect-fulfil, see A. Eide, 'Economic, Social and Cultural Rights as Human Rights' in A. Eide, C. Krause and A. Rosas (eds.), Economic, Social and Cultural Rights (Brill/Nijhoff, Leiden, 2001) 9. See also O. de Schutter, International Human Rights Law: Cases, Materials, Commentary (Cambridge University Press, Cambridge, 2010) 242 et seq. and 'Human Rights: Civil and Political Rights: The Human Rights Committee' Fact Sheet No. 15 (Rev. 1$) 5$.

15 Due diligence is a topic on which literature and case law (especially in the context of human rights) are abundant. Among others see, R. Pisillo Mazzeschi, 'The Due Diligence Rule and the Nature of the International Responsibility of States', 35 German Yearbook of International Law (1992) pp. 9-51; T. Koivurova, 'Due Diligence' (2010) Max Planck Encyclopedia of Public International Law; R.P. Barnidge, 'The Due Diligence Principle under International Law', 8 International Community Law Review (2006) pp. 81-122; V.P. Tzevelekos, 'Reconstructing the Effective Control Criterion in Extraterritorial Human Rights Breaches: Direct Attribution of Wrongfulness, Due Diligence, and Concurrent Responsibility', 36 
states to be proactive, inter alia, for preventive and, more generally, protective purposes irrespective of the nationality or statelessness of the individual concerned. ${ }^{16}$ The so called positive effect ${ }^{17}$ of human rights rules is associated with and stems from due diligence. As it is well known, the principle of due diligence establishes obligations of means/conduct. ${ }^{18}$ States are expected to make use of the means that are available to them in order to pursue - to the best of their ability - the goals of protection. Because states are sovereign, they enjoy discretion in choosing among several pertinent means that are available to them the ones they wish to employ.

Delimitation-wise, although due diligence and the doctrine of "Responsibility to Protect" (R2P) ${ }^{19}$ share a common core, ${ }^{20}$ the article does not consider

Michigan Journal of International Law (2014) pp. 129-178, at 152-157; First Report of the International Law Association Study Group on Due Diligence in International Law, 7 March 2014. The ICJ has in a number of instances employed due diligence. To give an example of explicit use, see Pulp Mills on the River Uruguay (Argentina v. Uruguay) (Merits), 20 April 2010, ICJ Rep 14, para. 101.

16 Osman v. UK, Application No. 23452/94, Judgment of 28 October 1998; VelásquezRodriguez v. Honduras, Judgment, Inter-American Court of Human Rights Series C No. 4 (29 July 1988), para. 172; J. Coppens, 'The Law of the Sea and Human Rights in the Hirsi Jamaa and Others v. Italy Judgment of the European Court of Human Rights' in Y. Haeck, E. Brems (eds.), Human Rights and Civil Liberties in the ${ }_{21}{ }^{\text {st }}$ Century (Springer, Heidelberg, 2014) 186.

17 Among others, see D. Shelton, 'Positive and Negative Obligations' in D. Shelton, A. Goult (eds.), The Oxford Handbook of International Human Rights Law (Oxford University Press, Oxford, 2013) 562-583.

18 A. Tunk, 'La Distinction des Obligations de Résultat et des Obligations de Diligence', $L a$ Semaine Juridique (Juris-Classeur Périodique) (1945) p. 449; P.M. Dupuy, 'Reviewing the Difficulties of Codification: On Ago's Classification of Obligations of Means and Obligations of Result in Relation to State Responsibility', 10 European Journal of International Law (1999) pp. 371-385; ECtHR, Xhavara and ${ }_{15}$ Others v. Italy and Albania, Application No. 39473/98, Judgment of 11 January 2001, 1; V. Moreno-Lax, 'Seeking Asylum in the Mediterranean: Against a Fragmentary Reading of EU Member States' Obligations Accruing at Sea', 23 International Journal of Refugee Law (2011) p. 193.

19 R2P is a relatively new but very dynamic concept in international law. Among several other titles, see Société française pour le Droit international, La Responsabilité de Protéger. Colloque de Nanterre (Pedone, Paris, 2007); J. Hoffmann and A. Nollkaemper (eds.), Responsibility to Protect. From Principle to Practice (Amsterdam University Press, Amsterdam, 2012); P. Hilpold, The Responsibility to Protect (R2P). A New Paradigm of International Law (Brill/Nijhoff, Leiden, 2014).

20 R.A. Barnes and V.P. Tzevelekos, 'Beyond Responsibility to Protect: Ceci n'est pas une pipe', in R.A. Barnes and V.P. Tzevelekos (eds.), Beyond Responsibility to Protect. Generating 
whether the duty to protect migrants could derive from that doctrine. In accordance with R2P, such an obligation could be triggered if migrants at sea were the victims of crimes such as genocide, war crimes and crimes against humanity. ${ }^{21}$ This would more generally raise a question of whether members of the international community are under a legal obligation ${ }^{22}$ to take (collective) action to protect third state nationals from such crimes. Interesting as it may be, this question is excluded from our analysis, which focuses on due diligence and the way it applies in the context of human rights law.

Moreover, it is not this study's aim to suggest any policies, strategies or best practices to the authorities entrusted with the protection of migrants. Our goal with this article is merely to establish in terms of positive international human rights law the duty of (more than one) state(s) to grant protection. How states will pursue this moral and legal task is a separate question that escapes our article. From our perspective, it suffices that state policies adequately serve the goals of protection and are compatible with international law. For instance, it has been suggested that a way to better address migration in Europe is to scrutinise who is entitled to be admitted before people arrive. ${ }^{23}$ An agreement

Change in International Law (Intersentia, Antwerp, 2016) 11-16; E. Katselli Proukaki, 'Commentary: R2P as a Transforming and Transformative Concept in the Context of Responsibility as Liability' in R.A. Barnes and V.P. Tzevelekos (eds.), Beyond Responsibility to Protect. Generating Change in International Law (Intersentia, Antwerp, 2016) 415-431.

Report of the International Commission on Intervention and State Sovereignty, The Responsibility to Protect, December 2001, paras. 4.19-4.20, <http://responsibilitytoprotect. org/ICISS\%2oReport.pdf>, visited on 19 February 2016. Ethnic cleansing obviously falls in other crimes covered by R2P.

22 Approaches on the legal status of R2P vary. See, for instance, C. Stahn, 'Responsibility to Protect: Political Rhetoric or Emerging Legal Norm?', 101 American Journal of International Law (2007) p. 99; A. Orford, International Authority and Responsibility to Protect (Cambridge University Press, Cambridge, 2011) 22-27; A. Pellet, 'What Normativity for the Responsibility to Protect?', in A.L. Vaurs-Chaumette and J.M. Thouvenin (eds.), La Responsabilité de Protéger; 10 Ans Après - The Responsibility to Protect; Ten Years On (Pedone, Paris, 2013) 185-191.

23 'A European Agenda on Migration', supra note 8, 8. See also the Opinion of the Advocate General of the Court of Justice of the European Union (CJEU) Mengozzi in the recent case $X, X$ v. Etat Belge, which concerned an application for a visa with limited territorial validity on humanitarian grounds submitted by a Syrian family to Belgium's embassy in Lebanon. Inter alia, the applicants argued that refusal to grant such visa would expose them to treatment contrary to Article 4 of the Charter of Fundamental Rights of the European Union which prohibits torture and inhuman or degrading treatment or punishment and which Belgium is under an obligation to uphold. This prompted Belgium to argue that its obligation under Article 4 did not extend to such extraterritorial visa applications. 
between European states (or the EU) and third states would enable the authorities of the former group of states to proceed with scrutiny outside their territory in co-operation with local authorities. This is an imaginative extraterritorial policy that may be perceived as better serving the interests of the receiving state, which, through that practice, may prevent migrants that it could lawfully remove from its territory from entering. As long as the state, "by using the device of changing the place of determination of their status", ${ }^{24}$ does not escape its duties under international (human rights) law vis-à-vis migrants, and especially refugees, such policies would be in principle permissible. $^{25}$

Another point pertaining to delimitation is that this study does not consider the responsibility of international organisations to protect or for their failure to protect, in the context of their mandate and foundational treaties (such as the Treaty of Lisbon in the case of the European Union). Rather, this article focuses on the responsibility of states which, acting on an individual capacity or as members of an international organisation, fail to meet their duty of

However, according to the Advocate General, the obligations under the Charter of Fundamental Rights are not subject to territoriality. To this effect, and since the application under consideration was covered by Eu law, the protections of the Charter extended to the applicants even if they were not within the territory of Belgium. In his view, "[i]t is ... crucial that, at a time when borders are closing and walls are being built, the Member States do not escape their responsibilities, as they follow from Eu law". Notably, protection from torture and inhuman or degrading treatment or punishment is so fundamental that it establishes both negative and positive obligations that require states to take reasonable steps to protect the individual concerned from such treatment. Opinion of Advocate General Mengozzi, $X, X$ v. Etat Belge, Case C-638/16 PPU, 7 February 2017, especially paras. $4,45,89,137-140$. Nevertheless, the case was later dismissed by the CJEU as not falling within $\mathrm{EU}$ law, noting that the relevant secondary E $\mathrm{U}$ legislation did not intend to enable determination of requests for international protection made outside the territory of the state concerned. By rejecting the applicability of EU secondary law, the Court escaped ruling on extraterritorial obligations flowing from the Charter of Fundamental Rights. $x$ and $x v$ Etat Belge, Judgment of the Court (Grand Chamber), 7 March 2017, especially paras. 45,49 .

24 Concurring opinion of Judge Pinto de Alburqueque, Hirsi Jamaa and others v. Italy, Application No. 27765/o9, Judgment of 23 February 2012.

25 See, however, P. van Berlo, 'The Protection of Asylum Seekers in Australian-Pacific Offshore Processing: The Legal Deficit of Human Rights in a Nodal Reality', 17:1 Human Rights Law Review (2017) pp. 33-71. The author discusses the transfer of migrants arriving irregularly in Australia to offshore processing centres in Nauru and the complex questions this practice raises from the perspectives of attribution, for the purposes of responsibility, and jurisdiction. 
due diligence and, in particular, the duty to protect human life, despite being legally required and able to do so.

The final delimitation point we ought to make regards the area of law, namely human rights, that we choose to focus on to build the three aforementioned main arguments. Admittedly, human rights law is not the only available and pertinent legal "avenue" in international law. The duty to protect (particularly, human life), as a reflection of the positive aspect of human rights, may additionally (i.e. beyond due diligence and human rights law provisions) arise from specific treaties or from the practice of international organisations. For instance, relatively recently, the Security Council adopted a resolution under Chapter viI of the Charter aiming "to sav[e] the threatened lives of migrants or of victims of human trafficking" at sea. With its resolution, the Security Council authorised states "to inspect on the high seas off the coast of Libya vessels that they have reasonable grounds to suspect are being used for migrant smuggling or human trafficking ...." ${ }^{26}$ In similar terms, it also invited states "with relevant jurisdiction ... to investigate and prosecute persons responsible for acts of migrant smuggling and human trafficking at sea .... ${ }^{27}$ Furthermore, examples may be given of international treaties outside stricto sensu human rights law that establish a duty to protect in circumstances such as the ones under consideration in this study. For instance, Article 16 of the Protocol against the Smuggling of Migrants by Land, Sea and Air Supplementing the United Nations Convention against Transnational Organized Crime establishes a duty to protect the rights of persons who have been subjected to smuggling and in particular the rights to life and safety of migrants. ${ }^{28}$ Moreover, other areas within the international legal order and especially the law of the sea ${ }^{29}$

26 UNSC Res. 2240, supra note 9, para. 7. For an overview of the law of the sea rules that apply for enforcement jurisdiction against migration see E. Papastavridis, 'Enforcement Jurisdiction in the Mediterranean Sea: Illicit Activities and the Rule of law on the High Seas', 25 International Journal of Marine and Coastal Law (2010) pp. 582-588.

27 UNSC Res. 2240, supra note 9, para. 15.

28 Article 16(3), Protocol against the Smuggling of Migrants by Land, Sea and Air Supplementing the United Nations Convention against Transnational Organized Crime, 15 November 2000, UNTS 2241, 507. The Protocol has currently 112 signatories and 143 states parties.

29 See for instance Regulation 15, Chapter v, International Convention for the Safety of Life at Sea, 1 November 1974, 1184 UNTS 3; International Convention on Salvage, 28 April 1989, UNTS 1953, 165, (especially Articles 8-11 and 16); and IMo 'Guidelines on the Treatment of Persons Rescued At Sea' (20 May 2004) Resolution MSC.167(78). On migration control within the various maritime zones under law of the sea, see R. Barnes, 'The International Law of the Sea and Migration Control', in B. Ryan and V. Mitsilegas (eds.), Extraterritorial 
contain special (as opposed to the general principle of due diligence) customary or treaty-stemming rules of international law that offer pertinent legal bases for the protection of migrants at sea. ${ }^{30}$ The most illustrious example to give is Article 98 of the 1982 United Nations Convention on the Law of the Sea (UNCLOS) that establishes a duty for vessels carrying the flag of a state party to render assistance to people and vessels in distress on the high seas - a duty that is also embedded in customary international law. ${ }^{31}$ UNCLOS also establishes an obligation upon coastal states to promote effective search and rescue mechanisms on and over the sea. ${ }^{32}$ Beyond UnCLOs, one may also refer to the 1989 International Convention on Salvage, ${ }^{33}$ the 1974 International Convention for the Safety of Life at Sea (solas) ${ }^{34}$ or the 1979 International Convention on Maritime Search and Rescue (SAR), ${ }^{35}$ which was amended in 1998 to attract a bigger number of signatories. ${ }^{36}$ SAR's principal aim is to facilitate the

Immigration Control. Legal Challenges (Nijhoff, Leiden, 2010) 117-133. More generally, on the interrelationship between human rights law and law of the sea, see, among others, B.H. Oxman, 'Human Rights and the Law of the Sea', in J.I. Charney, D. Anton and M.E. O'Connell (eds.), Politics, Values and Functions: International Law in the 21st CenturyEssays in Honor of Professor Louis Henkin (Kluwer Law International, Dordrecht, 1997); B.H. Oxman, 'Human Rights and the United Nations Convention on the Law of the Sea', 36 Columbia Journal of Transnational Law (1998) pp. 399-430; T. Treves, 'Human Rights and the Law of the Sea', 28 Berkeley Journal of International Law (2010) pp. 1-14.

See, for instance, Barnes, who discusses the 2001 Tampa incident and gives a comprehensive overview of the relevant legal framework from the perspective of the law of the sea regarding the rescuing of migrants at sea. R. Barnes, 'Refugee Law at Sea', 53 International and Comparative Law Quarterly (2004) 48-61. On the other hand, law of the sea also contains restrictions and conditions as to when a state can exercise jurisdiction, for instance, when visiting, boarding or seizing vessels on the high seas. See for instance Article 105 and 110 United Nations Convention on the Law of the Sea (UNCLOS), 10 December 1982, UNTS 1833, 397. On the international legal framework on search and rescue, see S. Trevisanut, 'Search and Rescue Operations at Sea', in A. Nollkaemper and I. Plakokefalos (eds.) The Practice of Shared Responsibility in International Law (Cambridge University Press, Cambridge, 2017) 428-435.

Article 98 (1), UNCLOS, supra note 30 . The convention has been ratified by 166 states. Also see Coppens, supra note 16,183 .

32 Ibid., Article 98(2).

33 International Convention on Salvage, supra note 29.

34 International Convention for the Safety of Life at Sea, supra note 29.

35 International Convention on Maritime Search and Rescue, 27 April 1979, 1403 UNTs.

36 See <http://www.imo.org/en/About/conventions/listofconventions/pages/international -convention-on-maritime-search-and-rescue-(sar).aspx > and <http://www.unhcr.org/uk/ news/latest/2006/6/44a56a724/maritime-conventions-amended-facilitate-search-and -rescue-sea.html>, visited on 15 February 2017. 
co-ordination of rescue operations at sea. For that purpose, it divides the world's oceans into a number of areas within which concerned states are responsible for search and rescue.

Arguably, SAR (and, more generally, the law of sea) may be seen as offering solid legal bases for the "right to be rescued at sea". ${ }^{37}$ If it exists, such a right will co-exist with human rights rules and the duty to protect (human life) that we discuss in this study. That being explained, the question to ask is why we choose here to focus on human rights law, instead of the law of the sea. We give three reasons explaining our choice.

First, it appears that no consensus exists in scholarship as to the existence in the law of the sea of a right to be rescued at sea and the conditions that would surround it. ${ }^{38}$ The relevant legal framework may be read as merely allocating competences ${ }^{39}$ rather than establishing actionable rights for individuals. Resorting to human rights law allows covering that "gap". Our analysis suggests that the right to be rescued and the corresponding duty for states to rescue are part of positive international human rights law and extend extraterritorially. Law of the sea offers the means that make it possible to achieve the ends of human rights law.

Second, for those who may disagree with the scholarly opinion (namely that law of the sea does not contain a right to be rescued at sea) underpinning our previous scenario, if we accept that both human rights and the law of the sea establish the right to be rescued, then the conclusion to reach is that these two regimes of international law complement each other. They may be understood as the two sides of the same coin, with rules stemming from the former regime (i.e. law of the sea) possibly acting as lex specialis that concretises state duties to protect human rights. ${ }^{40}$ The two regimes complement and reinforce each other. Besides, both normative frameworks, namely human rights and law of the sea, will be called to develop effects under due diligence. Thus, the obligations at issue will be of means, ${ }^{41}$ calling states to perform to the best of their

37 S. Trevisanut, 'Is There a Right to Be Rescued At Sea? A Constructive View', 4 Questions of International Law (June 2014) pp. 3-15, 5-8.

38 E.D. Papastavridis, 'Is There a Right to Be Rescued at Sea? A Sceptical View', 4 Questions of International Law (June 2014) pp. 17-32.

39 Ibid., pp. 21 and 23.

40 For instance, Butler and Ratcovich argue that "[t]he duty to rescue everyone in distress at sea can ... be seen as a natural corollary of the right to life". G. Butler and M. Ratcovich, 'Operation Sophia in Uncharted Waters: European and International Law Challenges for the EU Naval Mission in the Mediterranean Sea', 85:3 Nordic Journal of International Law (2016) pp. 235-260, at 253 .

41 Contra, Trevisanut, supra note 37, p. 4. Yet, the author accepts that this is a duty of due diligence. 
ability. In this respect, law of the sea rules may establish a framework for cooperation and co-ordination of action, set limits as to how a state can lawfully act by rendering compulsory or prohibiting certain conduct, grant competences, serve as the basis for action or set standards of conduct that diminish the discretion states enjoy in fulfilling their due diligence obligations (under human rights law). Overall, the interaction between the two regimes shall reinforce and specify the general duty states have to protect in the light of due diligence. Seen from that perspective, our article amounts to an invitation to international law lawyers specialising in the law of the sea to read its rules on rescue from the standpoint also of human rights law - and, in particular, from the angle that we suggest in this study that expands jurisdiction extraterritorially.

Finally, to move to the third reason as to why the questions raised in this study are examined from the perspective of human rights law, compared to the law of the sea, human rights offer more comprehensive and wide-ranging protection. For instance, the right to life is broad, encompassing a variety of elements and aspects beyond rescue, including the right for example to investigate the circumstances of loss of life - associated with the right to truth, i.e. the right of kin to know. ${ }^{42}$ Moreover, human rights do not only concern the right to life. To give an example, non-refoulement ${ }^{43}$ is central to migration

42 See, for instance, 'Assistance and cooperation in accounting for persons who are missing or dead in armed conflicts' UnGA Res. 3220 (XxIX) (6 December? 1974); 'Question of enforced or involuntary disappearances' UNGA Res. 47/32 (22 February 1993) UN doc. A/RES/47/133132 and Velásquez-Rodriguez v. Honduras Inter-American Court of Human Rights Series C No. 4 (29 July 1988), para. 181.

43 In this study, we employ the term "non-refoulement" in the widest possible way going beyond refugee protection law and, in particular, Article 33 of the $195^{1}$ Refugee Convention. The concept of non-refoulement that we employ here includes the case law of human rights institutions on the duty of states not to transfer (i.e. extradite, deport, expel, etc.) a person to a third state, where that person risks experiencing violations of her fundamental human rights. See the exemplary concurring opinion of Judge Pinto de Alburqueque, supra note 24. The ECtHR prohibits transferring a person to a country where she will risk a violation of Article 3 (torture, inhuman and degrading treatment) and 2 of the ECHR (life). Relatively recently, in Othman (Abu Qatada) v. United Kingdom (Application No. 8139/og, Judgment of 17 January 2012), the ECtHR expanded non-refoulement to the right to a fair trial, under Article 6 of the ECHR, to the extent that this could be associated with evidence collected through torture. Article 13 ECHR (effective remedies) has also been included in the list of rights the possible breach of which justifies the duty of states to abstain from transferring a person to a third country: M.s.s. v Belgium and Greece, Application No. 30696/og, Judgment of 21 January 2011, para. 286 et seq. and especially para. 293. See also Section 3 below and infra note 46 . 
as a "cardinal protection principle" 44 in refugee law. ${ }^{45}$ This has been developed by the European Court of Human Rights (ECtHR) as a human rights standard associated not only with the right to life but also with the prohibition of torture, degrading and inhuman treatment. ${ }^{46}$ Although it is expressed in negative terms (i.e. states have a duty not to return/transfer a person to a place where she risks suffering serious human rights violations), that duty corresponds to a means states ought to employ in order to protect individuals by preventing breaches of their fundamental rights (including the right to life).$^{47}$ Beyond any other policy states may choose to employ as a means to fulfil their due diligence obligations with regard to the right to life and the prohibition of illtreatment, international human rights law specifically requires them not to transfer a person to a state where such human rights violations may occur. ${ }^{48}$ Therefore, migration (through sea) raises, beyond rescue, a number of issues pertaining to human rights protection. This is yet another reason explaining our choice to employ that particular lens of analysis, while acknowledging that human rights are not self-contained. They should be implemented in harmony with other rules of international law (and in particular, in our case, with law of the sea rules) and duly integrated into the broader system of international law.

\section{Plurality of Protectors and Concurrent Responsibility}

Having concluded with the preliminary section that delimited the scope of the study, we now turn to the three main arguments we advance in it, starting with the reasons why plural (i.e. several) states ought to grant parallel protection and might, accordingly, be found concurrently responsible in case of failure to

44 UNHCR, 'Note on international protection' (13 September 2001) A/AC.96/951, para. 16.

45 Article 33, 1951 Convention Relating to the Status of Refugees.

46 See supra note 43. For instance, see Soering v. United Kingdom, Application No. 14038/88, Judgment of 7 July 1989; Saadi v. Italy, Application No. 37201/o6, Judgment of 28 February 2008; Dougoz v. Greece, Application No. 40907/98, Judgment of 8 February 2000 that concerns both Articles 2 and 3 of the ECHR. See also Un HRC, Kindler v. Canada, Communication No. 470/1991 (11 November 1993) UN Doc. CCPR/C/48/D/470/1991 especially paras. 6(2) and 13(1).

47 Tzevelekos, supra note $15,159-160$.

48 It could be argued that non-refoulement is a precondition for the right to seek asylum, which would otherwise be devoid of any meaning. 'Note on international protection', supra note 44, para. 16. For instance, the right to seek asylum is protected under Article 14 of the Universal Declaration of Human Rights, UNGA Res. 217 (III) A, A/Res/217 (III) A; and Article 22(7) of the American Convention on Human Rights, Pact of San Jose (1969). 
do so. Human migration is as old as humanity. ${ }^{49}$ People move from one place to another with the intention to make home the new location. And because land in our globe is divided into spheres of sovereignty exercised by states, the new home will inevitably be on the territory of a state. Migrants "nest" within a new state, expecting from it what all humans found under state sovereignty anticipate, i.e. first, that national authorities refrain from directly causing wrong to them, ${ }^{50}$ and, second, that they protect them..$^{51}$ Because, finally, jurisdiction is primarily territorial, ${ }^{52}$ once a person has entered - lawfully or unlawfully - the territory of a state, she is under the jurisdiction of that state.

49 Migration is used here lato sensu, comprising both (irregular) immigrants and refugees, although different regimes of protection may apply in each case, in the sense that there are special rules for the protection of refugees. Both aspects of migration are global phenomena that pose significant legal challenges in terms of protection.

5o In this article, by the term "causing" we mean wrongfulness that is directly attributable to a state. Direct attribution is juxtaposed to the concept of indirect attribution, which refers to indirect responsibility for lack of due diligence. See J. Salmon (ed.), Dictionnaire de Droit International Public (Bruylant, Brussels, 2001) 996 defining indirect responsibility as 'incurred by a subject of law because of the conduct of another subject of law' [our translation]. See also J.A. Hessbruegge, 'The Historical Development of the Doctrines of Attribution and Due Diligence in International Law', 36 New York University Journal of International Law and Politics (2003-2004) pp. 268-269. For a thorough discussion on causality and state responsibility, treating both direct attribution and indirect (omissions, fault, negligence etc.), see I. Plakokefalos, 'Causation in the Law of State Responsibility and the Problem of Overdetermination: In Search of Clarity', 26 European Journal of International Law (2015) pp. 471-492. See also Skogly who discusses causality (including direct and indirect responsibility) and state responsibility in an area contiguous to the topic of this article, namely extraterritorial violations of human rights. S.I. Skogly, 'Causality and Extraterritorial Human Rights Obligations' in M. Langford et al. (eds.), Global Justice, State Duties. The Extraterritorial Scope of Economic, Social and Cultural Rights in International Law (Cambridge University Press, Cambridge, 2013) 233-258. Gattini refers to the protective purpose causal theory, linking positive obligations (of due diligence) with causation. A. Gattini, 'Breach of International Obligations', in A. Nollkaemper and I. Plakokefalos (eds.), Principles of Shared Responsibility in International Law. An Appraisal of the State of the Art (Cambridge University Press, Cambridge, 2014) 30-31.

$5^{1}$ See supra note 14.

$5^{2}$ See for instance Banković and others v. Belgium, the Czech Republic, Denmark, France, Germany, Greece, Hungary, Iceland, Italy, Luxembourg, the Netherlands, Norway, Poland, Portugal, Spain, Turkey and the United Kingdom, Application No. 52207/99, 12 December 2001, para. 59. See also the references that the ECtHR makes to scholars supporting this point of view. For exceptions to territorial jurisdiction see L. Henkin, 'International Law: Politics, Values and Functions. General Course on Public International Law' (1989) IV RdC 280. 
However, before making a new home, migrants have to abandon an old one - that will most probably be on the territory of their state of nationality. Then, they have to cross borders, travel through the territory of other states and/or through high seas, which are open to all nations and where no state exercises (exclusively) sovereignty. Migration is a transnational phenomenon that involves as many states as the trip of a migrant comprises, plus the states of nationality of all involved actors. The state of departure, the state(s) of nationality (if these are different from the former state), the states through which a migrant transits and the state of destination are all engaged with the same transnational journey. That being explained, the first argument we are making in this article is that all involved states have the responsibility to offer, to the extent that each one of them can, protection. This leads to interlinked responsibility (in the sense of duty) to protect and, possibly, concurrent state responsibility (in the sense of liability) for failure to protect.

Admittedly, in principle, states exercise their jurisdiction (especially that pertaining to enforcement) within the confines of their territory. This offers the advantage of avoiding interfering with the sovereignty of other states, which respectively exercise jurisdiction over their national territory. The argument we wish to build here extends beyond that basic scheme. But, to explain that argument in the simplest possible terms, let us start by imagining for a moment that territory is the only basis for the exercise of jurisdiction in international law. Under that scenario, jurisdiction in the context of migration would be schematised in the following way. The state on the territory of which a migrant is found would be the one to exercise exclusive jurisdiction over her/ him. Because of jurisdiction, that state would have the duty to safeguard human rights, including the positive dimension of that family of rules, i.e. human rights protection. The state would have a duty of conduct/means to prevent any violations, and more generally, protect the fundamental human rights of the migrant. Because, finally, migration involves transition from one state to another until the migrant settles down permanently, a number of states would be expected to exercise jurisdiction in a row. This way, a queue of states is created. Each state should exercise its jurisdiction, including the responsibility to protect the migrant through prescriptive, enforcement and adjudicatory means, ${ }^{53}$ within the confines of its own territory.

53 See for instance the dissenting opinion of Judge Van den Wyngaert in the Arrest Warrant case, distinguishing between prescriptive jurisdiction and enforcement jurisdiction and arguing that, when the exercise of jurisdiction is permitted for states, it cannot lead to acts of extraterritorial enforcement. Dissenting Opinion of Judge Van den Wyngaert, Arrest Warrant of $n$ April 2000 (Democratic Republic of Congo v. Belgium) (Judgment), 14 February 2002, ICJ Rep 3, 168, para. 49. 
Jurisdiction may primarily be territorial, but other jurisdictional bases exist as well. ${ }^{54}$ Thus, to fully depict the jurisdiction network that surrounds migration, we need to take into account two more elements. First, the scheme is not that of a queue of states, but of a "chain". The difference between a queue and a chain is that the latter implies interconnection. For a chain to exist, a link between its rings is needed. We argue that, rather than a detached queue of states that exercise, one after another, exclusive jurisdiction in a row, on the basis and within the confines of national territory, the scheme that describes migration is that of overlapping and interlinked jurisdiction of more than one state over the same person and the situation that person is facing. What makes the jurisdiction of multiple states to cross, i.e. what establishes the connection between the rings of our fictional jurisdictional chain is the transnational nature of migration. This very nature expands state jurisdiction extraterritorially as the negative and positive obligations of the state continue to exist even if the migrant is no longer within its territory. For that to be true, jurisdiction cannotbe exclusively territorial. Hence, according to the second point, becauseagainst our initial, oversimplified scenario, confining jurisdiction to territory the latter is not the only basis of jurisdiction, more than one state can simultaneously exercise jurisdiction over the same situation. Thus, more than one state may be found concurrently responsible in the context of the same wrongful situation, which, in our case, consists in human rights violations suffered by a migrant. ${ }^{55}$ In the analysis that follows we examine these two points.

\subsection{The Transnational Nature of Migration and Extraterritoriality}

Starting with the transnational nature of migration, we need to take into account, first, the distinction between negative and positive human rights obligations, ${ }^{56}$ and second, that prevention/protection in the light of the positive scope of human rights may also apply when the threat to the enjoyment of these rights stems from a third state.

Starting with the former aspect, it is common knowledge that the distinction between negative and positive obligations corresponds to the two first strands of the aforementioned tripartite classification of human rights obligations

54 On the bases of jurisdiction see, for instance, C. Stalker, 'Jurisdiction', in M.D. Evans (ed.), International Law (4 ${ }^{\text {th }}$ edn, Oxford University Press, Oxford, 2014), 309-335. See also R. Higgins, Themes and Theories (Oxford University Press, Oxford, 2009) 801-810; C. Ryngaert, Jurisdiction in International Law (Oxford University Press, Oxford, 2008) Chapters 3 and 4 .

55 Goodwin-Gill, supra note 11, 447.

$5^{6}$ Supra notes 14,16 and 17. 
on the basis of respect, protection and fulfilment. ${ }^{57}$ The importance of differentiating between these two facets of state obligations lies in the fact that it allows understanding how the scope of an obligation changes. Protection is linked with the principle of due diligence. ${ }^{58}$ This is a well-recognised principle in international human rights law, associated with the obligation of states to take action to protect rights within their jurisdiction. ${ }^{59}$ Accordingly, states are required, not only to be neutral and refrain from directly causing ${ }^{60}$ wrongfulness (corresponding to the negative aspect of an obligation), but also to be proactive and make use of the means that are available to them in order to prevent and punish wrongfulness. This is a concept deeply embedded in general international law as well as in the law on state responsibility. States have a duty to take necessary action to prevent or end violations committed, for instance, by other subjects (i.e. not directly attributable to them) ${ }^{61}$

As far as the latter point is concerned, the threat to the rights of a migrant wishing to travel or being forced (extradition, expulsion, etc.) to move to another country may stem from the situations that she will face in that other country (i.e. the receiving country). The migrant might be exposed to the risk of experiencing serious human rights violations in that country because of the conduct of (i.e. attributed to) its authorities. ${ }^{62}$ Alternatively, human rights violations might be caused by third persons (i.e. other individuals) acting on the territory of the receiving country ${ }^{63}$ or even owing to general situations,

$57 \quad$ Supra note 14.

$5^{8} \quad$ Supra notes 15 and 16.

59 Among others, see L. Arbour, 'The Responsibility to Protect as a Duty of Care in International Law and Practice', 34 Review of International Studies (2008) pp. $445^{-458}$, at $45^{2}$.

6o See supra note 5 .

61 This is linked with due diligence and, in the context of human rights, with protection within the framework of the positive effect human rights develop (or horizontal effect, when the author of the breach is another individual). See supra notes 50, 14, 15, 16 and 17. See also, Case Concerning United States Diplomatic and Consular Staff in Tehran (United States of America v. Iran) (Judgment), 24 May 1980, ICJ Rep 3, paras. $5^{8}$ and 61; Draft Articles on Responsibility of States for Internationally Wrongful Acts with Commentaries 2001, Yearbook of the International Law Commission, 2001, Vol. II, Part Two, 39.

62 See for instance M.s.s. v Belgium and Greece, supra note 43, paras. 205-234 on detention conditions in Greece.

63 See for instance, H.L.R. v France, Application No. 24573/94, Judgment of 29 April 1997, para. 40. In 2005, thousands of migrants were dumped in the desert by Moroccan authorities. T Spijkerboer, 'The Human Costs of Border Control', 9 European Journal of Migration and Law (2007) p. 130. 
such as natural or social phenomena (war, poverty). ${ }^{64}$ In both cases (i.e. when the receiving state is the author of the wrongful conduct and when this is not directly attributable to it, but takes place on its territory), the state that transfers a person to the receiving state has a duty to protect her and not let her be exposed to the dangers that are associated with her movement/transfer to the receiving state. This is well-established in international human rights law. ${ }^{65}$ It reflects the rationale behind the rule of non-refoulement, ${ }^{66}$ that we have already mentioned, the ultimate raison d'être of which is to prevent the violation of the rights of a person in a third country. ${ }^{67}$ The state of departure (or sending state) has a legal obligation to assess the risk that exists for the person that it desires to remove from its territory or which it wishes to transfer away from its territory. If a danger exists in the receiving state for the migrant's fundamental rights (i.e. if it is not a safe destination), the sending state must demonstrate diligence by preventing her exposure to the danger. ${ }^{68}$

It is obvious that, in the scenario described here, we have moved away from clear-cut territoriality. ${ }^{69}$ The state on the territory of which the migrant is found is expected to prevent a wrong that may arise on the territory of another state (i.e. the receiving state). This is owed to the transnational nature of migration and explains why the jurisdiction exercised by the two involved states, i.e. the sending/transferring state and the receiving state, cannot always be detached, but intersecting and interlinked. This is a welcoming development in human rights law jurisprudence, as evidenced from the cases decided by the ECtHR, some of which are discussed in Section 3. Therefore, the transnational nature of migration means that more than one state is involved, thus more than one state has a duty to be diligent and extend its protection to the migrant, both territorially as well as for wrongs that might occur outside its

64 See for instance M.s.s. v. Belgium and Greece, supra note 43, para. 235 and following regarding the state of extreme poverty in which the applicant was living in Greece.

65 See supra notes 43 and 46.

66 See supra note 43.

67 According to Judge Pinto de Alburqueque, the duty to non-refoulement extends beyond the scope of protection afforded under the Refugee Convention to encompass risk to fundamental human rights for all persons. Concurring Opinion of Judge Pinto de Alburqueque, supra note 24 .

68 Among other cases, see Othman (Abu Qatada) v. United Kingdom, supra note 43, especially para. 194, where the Court explains that it "considers [that] the United Kingdom and Jordanian Governments have made genuine efforts to obtain and provide transparent and detailed assurances to ensure that the applicant will not be ill-treated upon return to Jordan".

69 Tzevelekos, supra note $15,158-159$. 
territory, i.e. extraterritorially, when it can prevent this from happening. This explains why multiple states-duty holders exist over the same situation. And as the next sub-section argues, they may all end up being concurrently responsible because of their failure to demonstrate due diligence (i.e. to protect the human rights of the migrant) from wrongs which are neither directly attributable to them (i.e. caused by them) nor necessarily taking place on their territory. ${ }^{70}$

\subsection{Beyond Territorial Jurisdiction}

To strengthen the second main point made earlier, namely that territory is not the only basis of jurisdiction, we can consider another scenario. As it is wellknown, modern migration is "facilitated" by smugglers. These are individuals who transport or, more, generally make possible the transportation and illegal entry of a person across international borders for financial or other material gain, in violation of one or more countries' entrance legislation..$^{71}$ The state on the territory of which smugglers act has a duty to take positive measures that will prevent smuggling from happening and put an end to it. ${ }^{72}$ Such measures fall under territorial jurisdiction and include investigation and punishment through the means that are available in the domestic legal system (for instance, criminal law). Especially when the conditions of transportation raise a risk for the life of the migrant, the aforementioned positive duty of the state on the territory of which the smuggler is acting corresponds to, and indeed stems from, the positive effect of the right to life.

In the case of transnational wrongs, "locus delicti" is equally transnational. In practical terms, this means that each state on and through the territory of which a smuggler acts has a duty to exercise (territorial) jurisdiction aiming to put an end to these acts. Thus, to take the example of transportation through sea, the smuggler will leave the territorial waters of one state and enter those of the destination state. Territorial jurisdiction requires the state on the territorial waters of which the smuggler operates to act in a protective manner for the life of the migrants. However, the fact that a smuggler is on the territory of the receiving state does not dissolve other states that are connected

$70 \quad$ The next session explains this argument in further detail. See also infra notes 77,80 and 81.

71 See also the definitions given in Article 3, Protocol against the Smuggling of Migrants by Land, Sea and Air, supra note 28.

72 Furthermore, states have a duty "to exercise due diligence to prevent and combat migrant smuggling and human trafficking, to investigate and punish perpetrators, to identify and provide effective assistance to victims of trafficking and migrants and to cooperate to the fullest extent possible to prevent and suppress migrant smuggling and human trafficking". UnSC Res. 2240, supra note 9. 
with the situation (i.e. trafficking of migrants) from their duty to demonstrate diligence against that wrong. Be it the primary one, territory is not the only basis for jurisdiction in international law. ${ }^{73}$ The state of nationality of the smuggler (active nationality), the boat's flag state (active nationality), the state(s) of nationality of the victim(s)/migrant(s) (passive nationality), the state on the waters of which the smuggler's boat navigates (territory), the destination and the departure ${ }^{74}$ states (territory) form a circle of states that are involved, sharing together the duty to be proactive and fight the situation at issue and the dangers this entails for human rights, and primarily for human life. The result is that of a plurality of duty bearers over the same situation. ${ }^{75}$ Each one of those duty holders has a different jurisdictional basis/nexus that links it to the situation, justifies its involvement and, indeed, generates/activates its duty to act in a protective manner, i.e. to demonstrate diligence. ${ }^{76}$ All connected states have a duty to engage in protection to the extent that they are linked and in ways justified by their connection to the situation. Failure by more than one state to demonstrate diligence results in concurrent responsibility/liability. ${ }^{77}$ Each state is individually ${ }^{78}$ responsible for its own failure to demonstrate the

73 Supra note 52 ; also see Stalker, supra note 54.

74 The duty of the state of departure to engage in the protection of the rights of migrants extends among others to their right to return home. See, F.Z. Giustiniani, 'The Obligations of the State of Origin of Refugees. An Appraisal of a Traditionally Neglected Issue', 30 Connecticut Journal of International Law (2015) pp. 171-208.

75 On multiple duty bearers see the collection of studies edited by W. Vanderhole, Challenging Territoriality in Human Rights Law. Building Blocks for a Plural and Diverse Duty-Bearer Regime (Routledge, Abbingdon, 2015). In relation to migration, the UN Security Council recognises "the roles and responsibilities of countries of origin, transit and destination in promoting and protecting the human rights of all migrants". unsC Res. 2240, supra note 9 .

${ }_{7} 6$ For instance, a state on the territory of which smugglers are acting has a duty to take action against them with a view to prevent the loss of human life. UnSC Res. 2240, supra note 9 .

77 Tzevelekos, supra note 15, 164 and following; see also Gammeltoft-Hansen and Hathaway, supra note $12,272-276$. The authors discuss shared responsibility in more general terms than concurrent responsibility, including in their analysis joint responsibility.

78 A. Nollkaemper, 'Introduction', in Nollkaemper, supra note 50, 9-10. In the example given by Nollkaemper, the two states are concurrently responsible for two separate wrongs that are directly attributable to them. That scenario might apply in the context of what we are discussing in this article, but the probability is that, in our case, we will have an accumulation of negative and positive human rights breaches, by two or more states, each one of which will be individually responsible for its own (either negative or positive breach). Nothing excludes that there is an accumulation of positive human rights breaches, i.e. 
degree of diligence that, given the circumstances of a particular case (which are different for each state), it would have been expected to demonstrate. In simpler terms, a person engaging in transnational criminal activities, such as human trafficking, may be prosecuted by the judicial authorities of as many countries as the ones linked with the criminal conduct at issue through one of the traditional jurisdictional links. Prosecution is one of the means that are available to each involved state to offer protection. States enjoy discretion in choosing the means they will employ to that end - but the principle of due diligence requires them to do the best they can. The transnational nature of the example discussed here results in a plurality of states engaging in protection simultaneously. Each state is expected to protect to the extent that it can, given its connection with the situation and in ways justified by the context and specifics of each case. The exercise of parallel jurisdiction by multiple nations means that overlaps may occur. Yet, this is inherent to the decentralised structure of international law and poses no problem as long as states exercise their jurisdiction (i.e. sovereignty) to demonstrate diligence in ways that are compatible with international law and respectful for the sovereignty of any other involved state. Finally, to achieve best results, states should ideally co-operate and co-ordinate their actions.

Thus, to conclude with this part of the analysis, transnational phenomena, such as migration, necessarily involve multiple states as well as actors, such as regional institutions like the $\mathrm{EU}$. This results in the exercise of complementary and often overlapping ${ }^{79}$ jurisdiction in the light of diligence by more than one state/actor - each one of them being involved on a different basis that links it to the situation, such as the protection of its nationals or the fact that the situation at issue is occurring on its territory. The failure of plural states to demonstrate diligence may result in a situation of concurrent responsibility over the

that several states show negligence in the duty each one of them individually has to protect. See Tzevelekos, supra note 15, 136 (fn 16) and 169. See also the analysis of Den Heijer, who explains why the breach of non-refoulemennt "gives rise to the state's independent rather than derivative responsibility". M. Den Heijer, 'Refoulement', in Nollkaemper and Plakokefalos (eds.), supra note 30, p. 496. In the same edited collection, Constantinides argues that in cases of extradition, "the sending state incurs independent responsibility based on the real risk of ill-treatment irrespective of the receiving state's actual conduct and responsibility". A. Constantinides, 'Extradition', in Nollkaemper and Plakokefalos (eds.), ibid., p. 150.

79 See Ryngaert's idea about reasonable jurisdiction and the distinction he makes between primary and subsidiary jurisdictional bases. Ryngaert, supra note 54, 185 and following. 
same wrongful harm (i.e. damage). ${ }^{80}$ Concurrent responsibility may take other forms as well and appear, for instance, as complementarity between negative and positive breaches of human rights in the context of transnational or extraterritorial situations. ${ }^{81}$ If a state, acting in breach of non-refoulement, transfers a migrant to a third state where she experiences serious human rights violations directly caused by state authorities, both the sending and the receiving state will be concurrently liable. One state because it has directly caused the wrongful result, breaking thereby the negative dimension of the human right at question, and the other because of its failure to prevent that breach, violating thereby the positive dimension of the same right.

\section{The Extraterritorial Effect of the Duty to Protect}

Against the idea of concurrent responsibility and multiple duty holders that we defend in our first argument, the hard reality is that migrants often receive significantly lower standards of human rights protection than the ones they are entitled to under international law. Their state of departure (which might also be their state of nationality) might be unwilling or genuinely unable to offer adequate protection or even be the source of sufferings for its people. This could also be among the reasons why people migrate. At the other end, the destination state - which is usually, but not always a developed country - does not engage with the situation until migrants have entered its territory. The problem is more obvious when high seas intervene between the departure/ transit and the destination states. ${ }^{82}$ Moreover, states often wash their hands of

80 See, for instance, M.s.s. v. Belgium and Greece, supra note 43, regarding the concurrent responsibility of Greece, because, inter alia, its state organs "indirectly" breached Article 3 ECHR by failing to protect the applicant who was living under conditions of extreme poverty (paras. 235-264) and Belgium, because it did not prevent this from happening by abstaining to return the applicant to Greece (paras. $323-368$ ).

$81 \quad$ Ibid.

82 The example may be given of the "Left-to-Die Boat" concerning migrants fleeing Libya in 2011 who ran out of fuel. In spite of repeatedly sending distress calls, none of the states and actors operating in the area provided substantial assistance. The migrants were left to drift for 14 days until they reached again the Libyan coast. Only 9 out of 72 migrants survived this ordeal. See C. Heller, L. Pezzani and S. Studio, 'Forensic Oceanography. Report on the "Left-To-Die Boat", <https://www.fidh.org/IMG/pdf/fo-report.pdf>, visited on 16 February 2017. 
the "burdens" of migration through "push back" policies. ${ }^{83}$ These policies present significant legal issues beyond the scope of this article, but also concern us here to the extent that such policies put human life at risk, either because of the high probability of deaths occurring at sea or because of the human rights violations a person might suffer if she returns to the state she abandoned before being pushed back to it. That being explained, the second argument in our study is that the duty of states to offer (some) protection extends extraterritorially, even when migrants are outside their territory ${ }^{84}$ or face risks for human rights violations that may materialise extraterritorially. That duty needs to be taken into account when states design policies aiming to prevent migrants from reaching their territory. Significantly, the duty extends to the high seas, in spite of the fact that the traditional links for establishing jurisdiction, such as territory, are absent in that case.

Whilst in recent years there are precedents confirming that state responsibility can be engaged for human rights violations occurring extraterritorially, such responsibility has been conditioned (especially in Europe) by the criterion of the effectiveness in the control exercised by a given state over territory or persons. ${ }^{85}$ Allegedly, this allows determining whether the violation concerned falls within state jurisdiction. However, questions remain regarding the acceptability of such a narrow, still, interpretation of jurisdiction, especially regarding the responsibility of states for failure to protect in situations occurring outside their territory. ${ }^{86}$ In the particular case of migrants at sea, there is a significant question as to whether contemporary international law imposes an obligation

83 For such policies pursued under Eu Frontex, see Moreno-Lax, supra note 18, 181. Similar policies were carried post-WWII towards Jewish refugees: D. Abbott, Refugees and Migrants (Search and Rescue operation), HC Deb, 30 October 2014, Col. 402.

84 On the UK position see J. Brokenshire, Refugees and Migrants (Search and Rescue operation), HC Deb, 30 October 2014, Col. 398.

85 The literature on extraterritoriality in human rights law and the criterion of effective control is vast. For a collection of essays, among others, see F. Coomans and M. Kamminga (eds.), Extraterritorial Application of Human Rights Treaties (Intersentia, Antwerp, 2004); see also Banković, supra note 52, especially para. 71. For a critique of the ECtHR effective control doctrine as a precondition for extraterritoriality, see Tzevelekos, supra note 15. In relation to economic and social rights, a number of approaches exist as to the criteria for the exercise of extraterritorial jurisdiction. See, for instance, Ryngaert who relies on the conduct-based doctrine regarding territorial conduct that produces adverse effects abroad. Thus, "individuals outside the State fall within its jurisdiction when certain acts or omissions of that State adversely impact on them". C. Ryngaert, 'Jurisdiction: Towards a Reasonableness Test', in Langford, supra note 50, 195.

See below, discussion in Section 3.2. 
upon states to take action to protect human life by rescuing migrants on the high seas. Our argument is that, whilst - as we explain in Section 4- the duty to protect is subject to limitations, under certain conditions, human rights law establishes a duty for (multiple) states to protect on the high seas. Consequently, it is possible to hold states responsible for their failure to offer such extraterritorial protection to migrants.

This section builds upon the preceding analysis and addresses in further detail the question of where protection is owed, providing specific examples of extraterritorial extension of the duty to protect in the context of migration. Our focus is situations at sea. We first examine seminal case law on non-refoulement. ${ }^{87}$ We then turn to our argument that, under certain circumstances, states have a duty to protect on the high seas even when the traditional nexuses for establishing jurisdiction, such as nationality, are absent.

\subsection{Non-refoulement at Sea}

A significant extraterritorial challenge that arises relates to the return of migrants intercepted or rescued at sea and the legality of "push back" policies implemented by numerous states through which they force vessels carrying migrants out of their jurisdiction. ${ }^{8}$ In Hirsi Jamaa and others v. Italy, ${ }^{89}$ the applicants, 11 Somali nationals and 13 Eritrean nationals were on board three vessels that departed from Libya and were headed to Lampedusa. When the vessels were still within the Maltese search and rescue area of responsibility, they were intercepted by the Italian authorities. All the migrants were transferred into Italian military vessels and returned to Libya in the light of bilateral agreements. According to the Council of Europe's Committee for the Prevention of Torture and Inhuman or Degrading treatment or Punishment, Italy's actions breached the principle of non-refoulement "wherever it exercised its jurisdiction, which included via its personnel and vessels engaged in border protection or rescue at sea, even when operating outside its territory". ${ }^{90}$ Italy, on the other hand, denied that it exercised absolute and exclusive control over the applicants, arguing that the duty under UNCLOS on rescuing vessels in

87 See Section 1 of the study and supra note 43 .

88 'Bangladesh PM says illegal migrants taint national image', supra note 6.

89 Hirsi Jamaa and others v. Italy, supra note 24.

9o Report to the Italian Government on the visit to Italy carried out by the European Committee for the Prevention of Torture and Inhuman or Degrading Treatment or Punishment from 27 to 31 July 2009, CPT/Inf (2010) 14, 28 April 2010, para. 49. 
distress did not establish a jurisdictional link. ${ }^{91}$ The ECtHR ruled that, since the applicants were on board Italian vessels, they were within the (de jure) jurisdiction of the respondent state because "a vessel sailing on the high seas is subject to the exclusive jurisdiction of the State of the flag it is flying".92 Whilst accepting that states have the right to control the entry, residence and expulsion of non-nationals in their territory, this right is subject to general international law and the European Convention on Human Rights (ECHR). ${ }^{93}$ By returning the migrants to Libya, Italy exposed them to the risk of forced repatriation as well as treatment prohibited under Article 3 of the ECHR. ${ }^{94}$

On a different, but quite significant point for the purposes of our argument, the Court was called to consider whether the interception of the applicants' vessels and their transfer back to the state of transit constituted a violation of Article 4 Protocol No. 4 ECHR, which prohibits the collective expulsion of aliens..$^{95}$ The government took a restrictive approach, arguing that expulsion was closely linked to territory. ${ }^{96}$ Both the applicants and third intervening parties in the case rejected this interpretation. ${ }^{97}$ In its intervention, the Office of the United Nations High Commissioner for Human Rights stressed that general international law prohibited collective expulsions of aliens and therefore, persons intercepted on the high seas and pushed back should be protected even if they have never reached that state's national territory. ${ }^{98}$ From its side, the ECtHR, by reference to the text, the travaux preparatoires and the object and purpose of the ECHR, held that there was no intention to restrict expulsion to that taking place in the territory of a member state. ${ }^{99}$ The ECtHR made the following important observations:

$91 \quad$ Hirsi Jamaa and others v. Italy, supra note 24, paras. 64-66.

92 Ibid., paras. 77 and 81. See also CAT, J.H.A. v. Spain, Communication No. 323/2007, 10 November 2008, para. 8.2, holding that, because the state "maintained control over the persons on board [a vessel] from the time the vessel was rescued [on the high seas] and throughout the identification and repatriation process", it (i.e. the state) exercised jurisdiction. CAT, inter alia, relies in that case on the effective control criterion for the establishment of jurisdiction. Regarding that criterion, see Tzevelekos, supra note 15.

Hirsi Jamaa and others v. Italy, supra note 24, para. 113 .

94 Ibid., para. 138 and previous paras. for the Court's reasoning.

95 On the conceptualisation of collective expulsion, see also Khlaifia and others v. Italy, Application No. 16483/12, Judgment of 1 September 2015, paras. 153-158. The case is currently under review by the Grand Chamber.

96 Hirsi Jamaa and others v. Italy, supra note 24, para. 160.

97 Ibid., paras. 161-165.

$98 \quad$ Ibid., para. 164.

$99 \quad$ Ibid., paras. $173^{-176 .}$ 
If, therefore, Article 4 of Protocol No. 4 were to apply only to collective expulsions from the national territory of the States Parties to the Convention, a significant component of contemporary migratory patterns would not fall within the ambit of that provision, notwithstanding the fact that the conduct it is intended to prohibit can occur outside national territory and in particular, as in the instant case, on the high seas. Article 4 would thus be ineffective in practice with regard to such situations, which, however, are on the increase. The consequence of that would be that migrants having taken to the sea, often risking their lives, and not having managed to reach the borders of a State, would not be entitled to an examination of their personal circumstances before being expelled, unlike those travelling by land. ${ }^{100}$

Thus, the obligations arising from Article 4 Protocol No. 4 apply extraterritorially. The Court explicitly refused to accept that individuals are unprotected by the ECHR in the high seas. ${ }^{101}$ According to the Court, immigration policies should not contravene ECHR obligations and "the provisions of treaties must be interpreted in good faith in the light of the object and purpose of the treaty and in accordance with the principle of effectiveness".102 Significantly, the Court stressed that:

the removal of aliens carried out in the context of interceptions on the high seas by the authorities of a State in the exercise of their sovereign authority, the effect of which is to prevent migrants from reaching the borders of the State or even to push them back to another State, constitutes

\footnotetext{
$100 \quad$ Ibid., para. 177.

101 Ibid., para. 178, explaining that "as regards the exercise by a State of its jurisdiction on the high seas, the Court has already stated that the special nature of the maritime environment cannot justify an area outside the law where individuals are covered by no legal system capable of affording them enjoyment of the rights and guarantees protected by the Convention which the States have undertaken to secure to everyone within their jurisdiction". The ECtHR explicitly refers in support of that view to Medvedyev and others $v$ France, Application No. 3394/03, Judgment of 29 March 2010, para. 81. See the critical comments by M. Szuniewicz, 'Problems and Challenges of the ECHR's Extraterritorial Application to Law-Enforcement Operations at Sea', 17 International Community Law Review (2015) p. 476. The author finds that Hirsi Jamaa undermines the ability of states to "hold back the influx of illegal immigrants", whereas that ability remains intact when migrants approach states by land. See also Barnes, supra note 30,64, who argues that an absolute refusal to allow disembarkation does not amount to a breach of non-refoulement.

102 Hirsi Jamaa and others v. Italy, supra note 24, para. 180.
} 
an exercise of jurisdiction within the meaning of Article 1 of the Convention which engages the responsibility of the State in question under Article 4 of Protocol No. $4 .{ }^{103}$

It appears from this that the Court indirectly accepts the position of the UNHCR that the duty not to return includes any measure "which could have the effect of returning an asylum-seeker or refugee" to a territory in which that asylumseeker's life or freedom may be at risk. ${ }^{104}$

The question of whether the mere diversion of vessels on the high seas to destinations where the individual may be exposed to violation of their fundamental rights is lawful has also been raised before the Inter-American Commission on Human Rights (IACommHR) in The Haitian Centre for Human Rights et al. v. United States. ${ }^{105}$ In this case, the applicants challenged the lawfulness of the us policy to interdict on the high seas and forcibly return Haitians without properly investigating individual claims for asylum. In its findings, the IACommHR stressed that the prohibition of return as stipulated in Article 33 of the 1951 Geneva Convention has "no geographical limitations"; hence it extended to the Us interdiction programme on the high seas. ${ }^{106}$ Moreover, the IACommHR found that the us was in breach of its obligations under the American Declaration of the Rights and Duties of Man and in particular its obligation to protect the life, liberty and security of any person. ${ }^{107}$ This was particularly so as a result of interdiction which in some instances led to the sinking of interdicted boats and the drowning of Haitians, as well as to returning interdicted Haitians to another jurisdiction where they were subjected to serious human rights abuses. ${ }^{108}$ Notably, the IACommHR found that the act of interdiction of vessels on the high seas was a violation of the right to liberty. ${ }^{109}$ The emphasis placed by the IACommHR on "the act of interdiction" provides compelling evidence that jurisdiction is extended and assumed even if the individuals concerned have not boarded the vessels of another state. ${ }^{110}$ Moreover, the

103 Ibid., para. 180.

104 'Note on international Protection', supra note 44, para. 16.

105 On the "lacuna" in Hirsi see Coppens, supra note 16, 202; The Haitian Centre for Human Rights et al v. United States, Inter-American Commission of Human Rights, Decision as to the merits of case 10.67513 March 1997, Report No. 51/96.

106 Ibid., para. 157.

107 Ibid., paras. 149 and following.

108 Ibid., especially paras. 163, 166-168.

109 Ibid., para. 169.

110 According to Moreno-Lax, effective control can be satisfied through rescue or interdiction, supra note 18, 218. 
expansive interpretation of the obligation of non-refoulement as protected under the Convention Relating to the Status of Refugees indicates that such duty is not "subject to geographic - or territorial - restriction".111

The cases above are significant as they establish that human rights obligations extend extraterritorially. This entails both a state's duty to respect human life, i.e. not to directly cause the death of migrants when forcibly interdicting them at (high) sea(s), as well as the duty to protect by abstaining from nonrefoulement practices at (high) sea(s) that will expose migrants to risks. This has also been stressed by the Parliamentary Assembly of the Council of Europe, which made clear that international human rights law and refugee law, such as the principle of non-refoulement, extend also to the high seas. ${ }^{112}$ Thus, apart from the law of the sea, human rights law also establishes a duty for states to protect human life at (high) sea(s). But, does this duty apply beyond nonrefoulement, especially when the traditional jurisdictional links/bases, such as territory and nationality are absent? This is the question we consider below.

\subsection{A Duty to Protect Where No Direct Nexus Exists?}

The existence of a nexus, such as territory, nationality or the protective principle, both enables and, when due diligence applies, obliges a state to exercise (through lawful means) jurisdiction and act as a protector in situations occurring outside its territory. But the question that we examine here is slightly different: beyond these classical nexuses or any other possible legal foundation, such as a contractual basis or, more generally, an obligation agreed by a government, do states have a duty to act in a protective manner when no such jurisdictional bases and links exist between them and a situation calling for protection? Protection has several dimensions and expands beyond nonrefoulement (i.e. the main topic we treated in the previous sub-section), which is rather passive, in the sense that a state needs to abstain from exposing a person to risks. The more concrete scenario we have in mind is one that requires pro-active involvement for protection purposes when, for instance, migrants are drowning in the high seas on their way to a destination state. For the purposes of the scenario, the migrants are approaching the territorial waters

111 E. Lauterpacht and D. Bethlehem, 'The Scope and Content of the Principle of NonRefoulement: Opinion', in E. Feller, V. Türk and F. Nicholson (eds.), Refugee Protection in International Law. Global Consultations (1 January 2003) 115, <http://www.unhcr.org/ 419c75ce4.html>, visited on 19 February 2016.

112 Parliamentary Assembly of the Council of Europe, Resolution 1821 (2011) on 'the interception and rescue at sea of asylum-seekers, refugees and irregular migrants', 21 June 2011, paras. 8 and 9.3. Also see Goodwin-Gill, supra note 11, 453 . 
of a state, but are not yet within that maritime zone - which would automatically establish a territorial link, activating thereby the due diligence duty of the territorial state to protect human lives. Would there be in such a scenario a duty stemming (outside the law of the sea) from human rights law for states to be pro-actively engaged in the protection of human life? If yes, which state(s) would be bound by said duty?

Our thesis is that in a scenario like that, despite the absence of traditional jurisdictional bases, the state of destination still has a(n) (extraterritorial) duty to protect human lives at risk. To support our argument we refer to effectiveness, i.e. the existence of factual/de facto links between a situation (migrants in peril on the high seas) and a state, that is to say, the mere fact that the migrants are nearby their destination state, which is aware of the situation (or could reasonably be expected to know) and in a position to save their lives. Effectiveness activates due diligence. ${ }^{113}$ Whilst jurisdiction is, as a matter of general rule, territorial, international law has created a dynamic for change and adjustment in pursuit of serving common interests. As noted by Henkin:

[i]ncreasingly ... the categories [for the exercise of jurisdiction] have proved to be too fixed - and perhaps too few - to serve the interests of States ... and the needs of the system (including new needs responding to new commitments to human values). Developments have blurred the traditional categories, suggesting that the assumption of rigid categories (territoriality, nationality) are no longer valid, and that a more flexible jurisprudence would better serve the purposes of the law and the needs of the system..$^{114}$

Our understanding is that effectiveness is among the factors/bases that activate the duty to protect. Such "duty of care" is "based on proximity, justice and reasonableness carrying with it an obligation to act reasonably on the basis of real or imputed knowledge".115 In the Corfu Channel case, the ICJ relied on "inferences of fact" to establish state knowledge and, as a result, state responsibility

\footnotetext{
113 Tzevelekos, supra note 15, 169-174; Y. Shany, 'Taking Universality Seriously: A Functional Approach to Extraterritoriality in International Human Rights Law', 7 The Law and Ethics of Human Rights (2013) p. 70.

114 Henkin, supra note 52, 291. Cf. The Case of the s.s. Lotus (1927) Series A, No. 10, PCIJ, 18-19, according to which jurisdiction "cannot be exercised by a State outside its territory except by virtue of a permissive rule derived from international custom or from a convention".

115 Arbour, supra note 59, $45^{2}$.
} 
for failure to act. ${ }^{116}$ Moreover, as Arbour argues, other factors may be included as well, such as the ability of other states to take protective action, but also resources, wealth and "advanced capabilities". ${ }^{117}$ Arbour, however, takes a more restrictive view than the one advanced in this article. More specifically, because her consideration evolves around R2P, she restricts the obligation of the international community to protect to situations of genocide, war crimes and crimes against humanity.118 According to Arbour's analysis, such responsibility does not extend to less serious human rights violations that may occur outside state territory. In contrast, we argue that the duty to take protective action originates from due diligence, which applies beyond the R2P concept. Such a duty extends to all human rights obligations when they develop a positive effect. Beyond the traditional jurisdictional links, due diligence can be activated when a state is factually connected to a situation calling for the demonstration of diligence. Thus, our argument is that effectiveness triggers due diligence. Every state that is factually connected with a situation calling for the protection of fundamental human rights, and especially of life, has a duty to grant protection.

The concept of effectiveness is not unknown to human rights lawyers working on extraterritoriality. The ECtHR holds that a form of effectiveness, i.e. effective control ${ }^{119}$ (and its variations) ${ }^{120}$ is a precondition for the ECHR to develop extraterritorial effects. According to that unfortunate standard of the ECtHR, effective control is necessary for establishing the extraterritorial jurisdiction of the state, and consequently its responsibility for wrongs it has

116 Corfu Channel Case (United Kingdom v. Albania) (Judgment), og April 1949, ICJ Rep 4, 18; Goodwin-Gill, supra note 11, 453 and 456 .

117 Arbour, supra note 59, 455 .

118 Ibid., 458.

119 Banković, supra note 5 , especially para. 71.

120 See, for instance, Issa v. Turkey, Application No. 31821/96, Judgment of 16 November 2004, paras. 74 (temporary effective control) and 75 (effective overall control), Medvedyev and others, supra note 101, para. 67 (full and exclusive control), Al-Skeini and other v. United Kingdom, Application No. 55721/07, Judgment of 7 July 2011, para. 149 ([public] authority and control). Obviously, for scholars who endorse the effective control criterion, the argument we are building here regarding the duty to protect migrants on the high seas is conditioned by said criterion. For instance, see E. Papastavridis, 'European Convention on Human Rights and the Law of the Sea. The Strasbourg Court in Unchartered Waters?', in M. Fitzmaurice and P. Merkouris (eds.), The Interpretation and Application of the European Convention of Human Rights. Legal and Practical Implications (Martinus Nijhoff Publishers, Leiden, 2013) 125. As the author argues, "[t]he application of the [ECtHR] on the high seas presupposes a certain degree of factual control on the vessel or on the persons that are to come under the jurisdiction of the boarding State". 
committed outside its territory. The limited space of this note does not allow us to repeat the argument that one of the authors of this article has made in the past as to why this criterion is groundless in the context of negative obligations. ${ }^{121}$ Our view is that when a state is directly causing a wrong, the role of effective control shall be limited to attribution (de facto organ) as a criterion for identifying the author of a wrong. ${ }^{122}$ After establishing the legal person to whom wrongfulness is attributable, effective control has no value for negative human rights breaches. States should not be allowed to directly violate human rights (and more generally international law) outside their territory, irrespective of whether or not they exercise effective control over a person, land or, more generally, a situation.

But, the scenario that we are examining here, namely the duty of states to rescue migrants on the high seas, focuses on the obligation to protect that falls under the positive effect of human rights. A state is expected to make good use of its resources, apparatus and, more generally, means that are available to it in order to prevent the loss of a human life. Admittedly, the ECtHR has not dealt with a case confirming our claim that effectiveness extends the duty to protect extraterritorially. Interestingly enough, though, its case law on the positive effect of human rights contains examples concerning the exact opposite situation to the one we examine in this article. In its seminal judgment in Ilaşcu, the Court held that "even in the absence of effective control" over part of its territory (found under the power of a de facto non-state entity which is effectively controlled by a third state government), a state still has positive human rights obligations. ${ }^{123}$ No matter whether the de jure territory of a state is de facto administered by another international legal person, the former's authorities have a duty to employ the means they dispose of to react against human rights breaches that are attributable to the latter person. Thus, a de jure (only, i.e. ineffective) territorial link suffices to engender the duty of a state to protect outside the territory it effectively controls. An alternative legal basis for establishing such a duty to protect could be nationality. Yet, Ilaşcu leaves wide open the possibility for a much broader duty to protect vis-à-vis each and every person found on territory which is under a state's de jure sovereignty but,

\footnotetext{
121 Tzevelekos, supra note $15,135^{-151 .}$

122 Ibid., 176. On Article 8 of the ILC norms on state responsibility and attribution of the conduct of de facto organs to states, among others, see K. Mačák, 'Decoding Article 8 of the ILC Articles on State Responsibility: Attribution of Cyber Operations by Non-State Actors', 21:3 Journal Conflict Security Law (2016) pp. 405-428.

123 Ilaşcu and others v. Russia and Moldova, Application No. 48787/99, Judgment of 8 July 2004, para. 331.
} 
de facto, out of its control. ${ }^{124}$ In that case, effective control misses its role as a precondition for extraterritoriality, whereas its absence (erroneously to our understanding $)^{125}$ seems to leave unaffected the standards of diligence a state shall be expected to demonstrate.

However, the scenario we examine here is diametrically opposite to the Ilaşcu one. That case law is relatively useful as it holds that the effective control criterion raises no constraints as to the establishment of jurisdiction for due diligence purposes. Yet, it does not confirm that effective control activates extraterritorial due diligence, as we argue here. Unlike Ilaşcu, where clear nexuses (namely nationality and de jure territory) existed, in our scenario of migrants drowning in the high seas, no legal nexus exists between the state and the situation calling for protection. How can it be then that a state that is not legally connected to an extraterritorial situation shall have an obligation to demonstrate diligence?

Our understanding is that effective control, seen as part of the much broader concept of effectiveness, is indeed pertinent to the establishment of jurisdiction for due diligence purposes. Effectiveness shall be added next to traditional legal nexuses/bases, such as nationality, territory and the protective principle, and next to any special legal basis (such as an agreed duty, or UNSC-stemming obligations) that may be used to establish the obligation of "A" to protect " $\mathrm{B}$ ". When a state is factually linked to a situation and in a position to offer protection, it shall offer protection. Ex facto jus oritur. ${ }^{126}$ Reality, i.e. the de facto links between a state and a situation necessitating protection for the safeguarding of important rights, turns into law. Trevisanut uses the example of a boat on the high seas that sends a distress call to argue that the state which receives such call has a duty to intervene, even if the boat is not within its territorial or other contractual (i.e. SAR) jurisdiction. Such duty is established on the basis of a factual relationship between the distress call and the state that receives the call in what she describes as "exclusive long distance de facto control".127 Even if the state is unable, due to the distance between itself and the boat in distress to

\footnotetext{
124 Ibid., para. 333 .

125 As we argue below, effectiveness in the exercised control is one of the criteria taken into account for assessing the fault/negligence of a state and answering what this was expected to do in terms of protection, given the particular circumstances of a case.

126 According to Distefano, 'Le principe de l'effectivité est le trait d'union entre le droit et le fait [...]'. G. Distefano, L'ordre internationale entre légalité et effectivité. Le titre juridique dans le contentieux territorial (Pedone, Paris, 2002) 257. Contra, see the sceptical approach by F. Couveinhes Matsumoto, L'effectivité en droit international (Bruylant, Brussels, 2014).

127 Trevisanut, supra note 37, 12-13.
} 
provide assistance, it is still required to take any measures that are necessary which go beyond those provided under SAR - to ensure that it satisfies its obligation to protect those in need. ${ }^{28}$

Indeed, the idea that effectiveness generates obligations is not novel to international law. Its legal order constantly vacillates between droit and fait, i.e. law and reality. ${ }^{129}$ The impact of effectiveness on law, that is to say, the transformation of facts into legal rights and duties is present in several areas of international law. It appears in the dilemma between legal and factual titles over territory. ${ }^{130}$ Fact is the basis (at least according to the declaratory theory) for statehood. ${ }^{131}$ Effectiveness is present in the attribution of conduct in the law of international responsibility, ${ }^{132}$ in the endowment with duties of de facto entities $^{133}$ and in the recognition of the legal effects of certain of their acts. ${ }^{134}$ In the context of diplomatic protection, effectiveness is of importance for making nationality opposable to third states. ${ }^{135}$ Effectiveness is also relevant to

128 Ibid., p. 13 .

129 Idea shared also by O. de Schutter, 'Globalisation and Jurisdiction: Lessons from the European Convention on Human Rights', CRIDHO Working Paper 2005/04, <http:// cridho.uclouvain.be/documents/Working.Papers/CRIDHO.WP.2005.04.pdf>, visited on 19 February 2016.

130 See, for instance, Distefano, supra note 126, 184 et seq.; R. O'Keefe, 'Legal Title Versus Effectivités. Prescription and the Promise and Problems of Private Law Analogies', 13 International Community Law Review(2011) pp. 147-188.

131 According to the declaratory theory, recognition shall have no legal effect on statehood, as this depends on a number of factual criteria, such as the existence of defined territory, permanent population and effective government. See J. Crawford, The Creation of States in International Law (Oxford University Press, Oxford, 2007) especially Chapter 2, at 37 and following.

132 See, for instance, Article 8 of the ILC norms on state responsibility (Supplement No. 10 (A/56/10), chp.IV.E.1) and Article 7 of the ILC norms on the responsibility of international organisations (A/66/10, para. 87).

133 Tzevelekos, supra note 15, 166-168. See also the PhD thesis of A. Berkes, “Grey Zones": The Protection of Human Rights in Areas out of the Effective Control of the State', Université Paris 1 Panthéon-Sorbonne, defended on 22 November 2015, 353-394 (on file with the author).

134 See, for instance, Legal Consequences for States of the Continued Presence of South Africa in Namibia (South West Africa) Notwithstanding Security Council Resolution 276 (1970) (Advisory Opinion), 21 June 1971, ICJ Rep, 16, 56, para. 125 .

135 Nottebohm case (Second phase) (Judgment) o6 April 1955 ICJ Rep, 4, 22-24. But see the ILC commentaries on Article 4 of the 2006 Articles on Diplomatic Protection (Yearbook of the International Law Commission, 2006, vol. II, Part Two) 32-33, para. 5. See also Article 7 of the ILC Articles on Diplomatic Protection (Official Records of the General Assembly, Sixtyfirst Session, Supplement No. $10 \mathrm{~A} / 61 / 10$ ), which prevents a state from exercising diplomatic 
treaties: "a treaty must be interpreted so as to have the 'appropriate effects"'.136 This is particularly important in the case of human right treaties. Effectiveness (i.e. the effet utile ${ }^{137}$ of human rights law) requires that these treaties do not create illusory or theoretical rights, but rather rights that are practical and effective, ${ }^{138}$ in accordance with their object and purpose. ${ }^{139}$ The Convention Relating to the Status of Refugees, for instance, would remain ineffective had it been interpreted in a way permitting de facto refoulement before entry in the territory of a state. ${ }^{140}$

In a nutshell, effectiveness is relevant to law. It produces legal effects and generates legal rights and obligations. In the context of extraterritorial human rights protection, the existence of factual links between a state and a situation susceptible to due diligence duties shall suffice for the expansion of these duties beyond the territory of a state. Within a decentralised system that accommodates a plurality of sovereign actors and (as the previous part of the article has argued) multiple duty bearers, the existence of effective links between a state and a situation calling for the demonstration of due diligence shall activate the obligation of the state to develop such diligent conduct. This is consistent with the teleology of human rights and their special aim, which is to protect important values, and especially human life. It is also an "elementary consideration of humanity". ${ }^{141}$ For international human rights law to be effective, state jurisdiction ought to be expanded to circumstances where human life is under risk, such as in the case of transportation of migrants. ${ }^{142}$ The duty

protection in favour of its national against a third state of which that person is also a national unless the nationality of the former state is predominant. Predominance is a matter of effectiveness. ILC commentaries on Article 7 of the 2006 Articles on Diplomatic Protection 43-47.

136 M. Pallis, 'Obligations of States towards Asylum Seekers at Sea: Interactions and Conflicts Between Legal Regimes', 14 International Journal of Refugee Law (2002) pp. 329-364, at 337 .

137 ILC, Fragmentation of International Law: Difficulties Arising for the Diversification and Expansion of International Law, Report of the Sturdy Group of the International Law Commission, A/CN.4/L.682, 13 April 2006, 216, para. 428.

138 This is well established in the case law of the ECtHR. For example, Airey v. Ireland, Application No. 6289/73, Judgment of og October 1979, para. 24.

139 D. Rietiker, "The Principle of "Effectiveness" in the Recent Jurisprudence of the European Court of Human Rights: Its Different Dimensions and Its Consistency with Public International Law - No Need for the Concept of Treaty Sui Generis', 79 Nordic Journal of International Law (2010) pp. 245-277, 256 et seq.

140 Pallis, supra note 136,355 .

141 Moreno-Lax, supra note 18, 192.

142 We owe that idea to discussions we had with Dr A. Berkes. 
of adjacent coastal states to offer assistance to foreign ships in distress ${ }^{143}$ emanates from this concept of effectiveness. It goes without saying that a number of other "ingredients" are also necessary. The state must be aware of the situation/problem/risk that exists for human rights, ${ }^{144}$ and in a position, ${ }^{145}$ i.e. have the necessary means, to offer protection. Yet, these are elements for assessing state fault ${ }^{146}$ that need to be taken into account once the duty to protect has been established. Within the scheme suggested here, the existence of effective links between a state and a situation necessitating protection is a sufficient, although not necessary, precondition for the duty to protect to expand extraterritorially. This is also a reflection of the "growing flexibility and functionalism in international law", 147 from which the concept of jurisdiction could not escape, as well as the growing scope and significance of human rights.

To return to our scenario, when migrants are in the near proximity of the territory of a receiving state, that state cannot hide behind territoriality as a pretext to refuse granting protection. That would be an artificial, formal restriction that contravenes the very nature and teleology of human rights protection. This extends to risks ensued when the individual concerned is still outside the territory of a state. According to Judge Pinto de Alburqueque:

[p] roximity to the sources of risk makes it even more necessary to protect those at risk in their own countries. If not international refugee law, at least international human rights law imposes on States a duty to protect in these circumstances and failure to take adequate positive measures of

143 The MV Toledo, High Court (Admiralty) (Ireland), 7 February 1995, (1995) 2 ILRM 30, 48-9.

144 See, for instance, Case Concerning United States Diplomatic and Consular Staff in Tehran (supra note 61), para. 68. In the context of extraterritoriality, see for instance UNHRC, Munaf v. Romania, Communication No. 1539/2006, CCPR/C/96/DR/1539/2006, 13 July 2009, para. 14.2.

145 Case Concerning United States Diplomatic and Consular Staff in Tehran (supra note 61), para. 68. See also Application of the Convention on the Prevention and Punishment of the Crime of Genocide (Bosnia and Herzegovina v. Serbia and Montenegro) (Judgment) 26 February 2007, ICJ Rep, 43, para. 430.

146 Among others, P.M. Dupuy, 'Le fait générateur de la responsabilité internationale des États', 188 RdC (1984) pp. 102-103; Pisillo Mazzeschi, supra note 15, 18-21, 49-50; Tzevelekos, supra note 15, 155-157; A. Gattini, 'La notion de faute à la lumière du projet de convention de la Commission du droit international sur la responsabilité internationale', 3 European Journal of International Law (1992) pp. 253-284; A. Gattini, 'Smoking/No Smoking: Some Remarks on the Current Place of Fault in the ILC Draft Articles on State responsibility', 10 European Journal of International Law (1999) pp. 397-404.

147 Henkin, supra note 52, 277. 
protection will constitute a breach of that law. States cannot turn a blind eye to an evident need for protection. For instance, if a person in danger of being tortured in his or her country asks for asylum in an embassy of a State bound by the European Convention on Human Rights, a visa to enter the territory of that State has to be granted, in order to allow the launching of a proper asylum procedure in the receiving State. This will not be a merely humanitarian response, deriving from the good will and discretion of the State. A positive duty to protect will then arise under Article 3. In other words, a country's visa policy is subject to its obligations under international human rights law. 148

Geographical proximity or contiguity is a criterion that has also been highlighted by the International Court of Justice in its judgment in the genocide case opposing Bosnia and Herzegovina, and Serbia and Montenegro. ${ }^{149}$ The Court named geographical distance among the factors that should be taken into account for assessing the capacity of a state to act in a protective manner, which is a key issue for answering the question of whether a state has discharged its duty to protect. ${ }^{150}$ It seems that the Court is seeing geographical distance as a relevant element for assessing state fault, ${ }^{151}$ i.e. examining what the state could do, which, because due diligence is an obligation of means, equates to what a state ought to do. However, that very same criterion, namely geographical distance could be given another role as well. The Court could have treated contiguity as another relevant factor for assessing how real, effective and tangible are the links between a state and a situation calling for diligence. If we accept that effectiveness triggers the duty to protect extraterritorially, geographical proximity is an element among other factors ${ }^{152}$ that ought to be weighted for

148 Concurring Opinion of Judge Pinto de Alburqueque, supra note 24. See also K. Vaz, Refugees and Migrants (Search and Rescue operation), HC Deb, 30 October 2014, Col. 401.

149 Application of the Convention on the Prevention and Punishment of the Crime of Genocide, supra note 145 .

$150 \quad$ Ibid., para. 430.

151 See supra note 146.

152 Effectiveness is a matter of fact. This means that all relevant factual elements that may strengthen or weaken effectiveness shall be duly considered. Otherwise, without weighting these elements, the general criterion of the ability to protect would result in quasiunlimited jurisdiction and to unreasonable burden for states to offer protection in cases with which they are either remotely or completely unrelated. The factual elements that ought to be taken into account for establishing effectiveness (acting as a trigger for due diligence) depend on the particular circumstances of each case. In the scenario that we are examining here, beyond proximity, factors to be considered would be the regular 
assessing whether a state could intervene in a protective manner. Thus, it is an element to be taken into account for establishing the ability/capacity of a state to protect. Accordingly, capacity is assigned a twofold role. It is both an element within the test of state fault, part of which is to assess the standards of conduct of the state (i.e. establishing what the state could do, ergo what it would be legally expected to do, and if it has been negligent), and an element of effectiveness (i.e. how effective is the nexus between a state and a situation requiring protective action), which, to our understanding, activates due diligence. If a state is effectively in a position to protect fundamental rights, then it has a duty to protect them, even when the traditional legal bases for jurisdiction are missing. Such duty extends to decisions relating to places regarded as safe for the disembarkation of migrants in third state ports, despite the lacuna that seems to exist in the Convention of the Law of the Sea, as well as to permitting a vessel to reach a port. This emanates from "a positive obligation to preserve human life". 153

It goes without saying that, because protection is an obligation of means, the state can choose the means it will employ to protect on the high seas. For instance, one would expect states not only to directly engage in protection on the high seas, but also facilitate individuals who may ${ }^{154}$ offer such protection. Thus, the expectation would be that states refrain from enacting and implementing laws that undermine or hurdle the protection that might be offered by individuals. The example that we could give in that respect is that of the criminal prosecution of three German nationals by Italian authorities for aiding and abetting illegal immigration. The individuals concerned were members of a German aid ship, the Cap Anamur. In 2004, the ship was involved in the rescuing of 37 migrants off the Maltese coast, but when it approached Sicily, the Italian authorities refused to grant it permission to dock on the ground. This was thought to set a bad precedent, as migrants should have applied for asylum in Malta. ${ }^{155}$ It took three weeks before the ship was allowed to dock. The three men faced 12 years in prison as well as EUR 15,000 fine for every

patrolling activity of the state, whether that state is usually a destination for migrants, if a situation (such as war or political tensions) in the area results in systematic migration, knowledge on the part of the state of the presence of migrants thanks to technical means etc.

153 Moreno-Lax, supra note 18, 175 and 219.

154 Either systematically, as NGOs do, or even occasionally, when out of mere coincidence they happen to be in a position to demonstrate solidarity by rescuing, for instance, migrants at risk at (high) sea(s).

155 Article 13 (1), Regulation No. 604/2013 of the European Parliament and of the Council, 26 June 2013, OJ L 180/31. 
migrant they brought into the country. They were finally acquitted in 2009.156 This case is a clear example of how state action - such as for instance sea border control policies - producing extraterritorial effects may implicate state responsibility for human rights violations, as confirmed by the ECtHR. ${ }^{157}$ As pointed out:

[t]he obligation of a State to take appropriate steps to safeguard lives is not conditioned on a causal relationship between the State's actions and someone's death. Rather, the obligation is triggered by the State's knowledge that a particular life is at risk and that same State's ability to do something about it. ${ }^{158}$

The conclusion is that, especially where a systematic problem exists, as is currently the case in the Mediterranean, the receiving states have a duty to act in a diligent manner beyond their territory. Such duty extends to border control policies, especially at sea, which may put human life at risk. ${ }^{159}$ It goes, finally, without saying that the conclusions reached in the previous paragraph of the article remain pertinent. A plurality of duty bearers exists. The list with states that may possibly be involved shall be enriched with those states that are factually linked to a situation. Every time a migrant is drowning in the high seas, a plurality of states, including the state of her/his nationality,

156 Tribunale di Agrigento, I Sezione Penale, I Collegio, 7 October 2009, <http://www.giureta .unipa.it/Tribunale_Agrigento.pdf>, visited on 19 February 2016. See also, 'Italy acquits migrant rescue crew', ввс News (7 October 2009) <http://news.bbc.co.uk/1/hi/8295727.stm>, visited on 19 February 2016. In 2002, the EU adopted rules to crack down on migrant smuggling: Directive 2002/90/EC establishing a common definition of the offense of facilitation of unauthorised entry, transit and residence [2002] oJ L 328/17) and Framework Decision 2002/946/JHA on the strengthening of the penal framework to prevent the facilitation of unauthorised entry, transit and residence [2002] OJ L 328/1. See also, EU Regulation $656 / 2014$ [2014] OJ L 189/93 on 'establishing rules for the surveillance of the external sea borders in the context of operational cooperation coordinated by the European Agency for the Management of Operational Cooperation at the External Borders of the Member States of the European Union'. According to para. 14 of the preamble, "[ $[$ ] he shipmaster and crew should not face criminal penalties for the sole reason of having rescued persons in distress at sea and brought them to a place of safety". Article 4 of the Regulation is devoted to human rights and non-refoulement and Article 9 on search and rescue.

157 Ilaşcu and others v. Russia and Moldova, supra note 123, para. 317.

158 T. Spijkerboer, 'The Human Costs of Border Control', 9 European Journal of Migration Law (2007) pp. 127-139, at 138. On state responsibility for acts with 'proximate repercussions' on human rights occurring extraterritorially see de Schutter, supra note 129.

159 Spijkerboer, supra note $15^{8}, 13^{2}$. 
the state of nationality of traffickers and the state in the proximity of which the human life has been lost, need to be checked regarding the standards of diligence they (ought to have) demonstrated. Such a test may reveal that a plurality of states is concurrently responsible. Due diligence being an obligation of conduct, states enjoy discretion in choosing the means that they will deploy to protect human life. The use of a variety of means, ranging from the exercise of prescriptive jurisdiction, enforcement of legislation and sanctioning of illegal conduct to naval operations on the high seas, may be pertinent. As long as these means are lawful in terms of international law (which of course excludes use of force on the territory of other countries against non-state actors involved in smuggling or illegal trafficking), states are free to make use of them. Finally, given that multiple means/measures exist as options in the hands of multiple duty bearers, co-operation between duty bearers is necessary so that action is co-ordinated and efficient. ${ }^{160}$

\section{$4 \quad$ The Limits of the Duty to Protect (Extraterritorially)}

Before concluding the article, a few words are due regarding the limits of the duty to protect (extraterritorially). The reason why the word "extraterritorially" is placed in a parenthesis is that the limits of the duty to protect are the same irrespective of whether jurisdiction is territorial or not. In different words, these limits are irrelevant to extraterritoriality.

The first source of limitations is inherent to due diligence. Elements such as knowledge and capacity to protect are part of the state fault test. ${ }^{161} \mathrm{~A}$ state has a duty to prevent or, more generally, protect only if it (is reasonably expected to) know(s) or foresee(s) the existence of a problem/risk/threat. As far as capacity is concerned, due diligence is merely an obligation of means/conduct. ${ }^{162}$ States are not expected to guarantee a given result (for instance that the life of a migrant will be saved). They only need to do what is possible, to the best of

\footnotetext{
160 Güzelyurtlu and Others v. Cyprus and Turkey, Application No. 36925/o7, Judgment of 04 April 2017. The two respondent states have been condemned by the ECtHR for failure to co-operate in investigating transnational crime leading to the loss of human lives. The duty to co-operate was found to derive from the positive effect of the right to life. This contains a procedural aspect that, in the context of the case at issue, required from the two involved states to co-operate as a means to effectively investigate the circumstances that led to the murders.

161 Supra notes 144, 145 and mainly 146.

162 Supra note 18; and Application of the Convention on the Prevention and Punishment of the Crime of Genocide, supra note 145, para. 430.
} 
their ability, to achieve the optimal result. In that respect, effectiveness (in the exercised control) serves as one of the criteria for establishing the standards of conduct expected from a state (that is to say, a criterion helping to answer what the state ought to have done to address a situation requiring from it to demonstrate diligence) and, consequently, for assessing its fault/negligence in case of failure to meet these standards. ${ }^{163}$ The more effective the control a state exercises, the more it can do. The more it can do, the more it is legally expected to do in the light of due diligence.

The second type of limitation is not exclusive to due diligence. It applies to all human rights in both their negative and positive dimension, as long as these are not absolute. Rules that are not jus cogens may be limited either in case of (occasional) conflict with other rules of international law, including human rights law or, more often, because of general/public interest purposes. The tool commonly used to assess the legality of a limitation is proportionality, ${ }^{164}$ which also finds an application every time the question is whether the means a state shall employ for due diligence/protective purposes are disproportionately affecting general interest or the rights of others.

The third and final limitation that we can identify could be seen as falling within the concept of general interest that counterbalances the aim of protection in the context of proportionality. However, because the limitation at issue is special to due diligence, we can mark it as a distinctive type of limitation. Unlike negative obligations, where the state shall simply refrain from directly causing ${ }^{165}$ - through conduct directly attributable to it - a wrongful result, positive obligations require states to make use of the resources and means that are available to them. The most apparent difference between negative and positive obligations is that the former class is of result, whereas the second of means. A number of consequences stem from that differentiation. Many of them are obvious and have already been employed in this article; for instance, state fault is applicable in the case of obligations of means to test the ability of the state to act. Another, less obvious this time, difference between negative and positive obligations is that the second type of duties always has an economic cost. In principle, negative obligations have zero cost. The state is simply expected to be neutral, to abstain, that is to say, to refrain from doing something. Quite the opposite, positive obligations cost. Often, costs will be minimal. But even to enact a law (prescriptive jurisdiction) has some cost. The running costs for

163 Tzevelekos, supra note 15, 176; also see Coppens, supra note 16, 186.

164 See for instance the critical analysis of R. Alexy, 'Constitutional Rights, Balancing, and Rationality', 16 Ratio Juris (2013) pp. 131-140.

165 See supra note $5^{0 .}$ 
deliberations before law-making institutions at the national level, even the paper that will be used to print a law, cost. Given that there is a wide range of means a state can/ought to employ to fulfil its positive obligations under human rights law, we can safely conclude that there is an equally wide range of costs. Printing a law incurs minimal economic cost, but running a wellequipped and well-trained police or patrolling and operating on the high seas to rescue migrants requires spending significant amounts of public money.

That being explained, it is easy to understand that positive state duties under modern international law in areas like human rights, environmental protection, cultural heritage, etc., which all can produce results under the principle of due diligence, require employing a wide spectrum of policies and an equally considerable range of means for protective purposes. Yet, resources within a state are by definition limited. What is not limited is the list of positive duties a state has, which all involve public money expenditure. It might be that due diligence obligations are of means, meaning that a state only needs to protect to the extent that it can, but it is obvious that, if priority is given to " $\mathrm{x}$ " protective aim (such as rescuing migrants on the high seas), that aim will limit a state's capacity to apply protective means/policies in other areas (e.g. human trafficking, deforestation, national security or even social policies such as education and health) that also require protection, due diligence and spending public money. The money spent for " $\mathrm{x}$ " protective policy is money that cannot be spent for (protective) policy "z". Or, standards in (protective) policy " $z$ " will be underfinanced to the extent that policy " $x$ " is financed. This means that positive duties find themselves in a course of latent conflict. To resolve that conflict it is necessary to establish priorities and set the standards of protection by which a state needs to abide.

This raises a number of thorny questions regarding the criteria that should be applied for setting positive conduct standards and establishing priorities, but also regarding the organs/institutions that should have the authority within a liberal democracy to do so, and in particular whether these are questions to be answered by courts or parliaments, which reflect popular sovereignty and express the will of social majorities. ${ }^{166}$ These (ultimately philosophical) normative (i.e. as to how things should be) questions cannot be answered in this article. We limit our analysis to positive law standards the way these have been set and interpreted by courts. That being explained, we observe that, with its rich non-refoulement case law, the ECtHR has only requested states to demonstrate due diligence regarding the protection of

166 See, for instance, M. Klatt, 'Positive Rights: Who Decides? Judicial Review in Balance', 13 International Journal of Constitutional Law (2015) pp. 354-382. 
the most fundamental rights, such as the right to life and the prohibition of Article 3 ECHR breaches. ${ }^{167}$ Presumably, the reason why that Court has allowed itself to establish standards of protection in these areas is that, in its eyes, these rights are materially/ethically weighty. The Court gives greater value to these rights and implicitly prioritises them over other human rights that develop a positive effect and, more generally, other areas of protection. The same logic applies in the question examined in this study, i.e. the duty to protect migrants on the high seas. To this effect, "political convenience or economic cost" are not a good excuse and should not exempt states from their obligations under international human rights law ${ }^{168}$ and in particular from their duty to take the measures one would reasonably expect them to take in order to protect human life at sea, both territorially and extraterritorially.

\section{5 Conclusion}

We acknowledge that rescuing migrants (at sea) is costly and that the means/ money used for that purpose could be used by a state for other, equally legitimate, but more beneficial for its own citizens, purposes. However, saving the life of a person who faces a serious risk/threat shall be a priority for our societies. The effective links that exist between a state and persons travelling to it through high seas in quest of a better life or because of fear of persecution activate that state's duty to act in a protective manner extraterritorially. The duty of states to make available "sufficient resources" for the implementation of policies aiming at protection emanates from the positive strand of human rights as set out in treaties, such as the International Covenant on Civil and Political Rights. ${ }^{169}$ This is particularly so as the rights at stake in relation to migrants who flee other jurisdictions and seek protection elsewhere are recognised as having particular importance. More specifically, the right to life establishes a duty on the state "to do all that could be reasonably expected", whereas the prohibition not to be subjected to torture or to inhuman or degrading treatment or punishment establishes a duty on the state to ensure protection against such treatment. ${ }^{170}$ The fact that at stake is the protection of human life, the number of people dying at sea (especially in the last few years, in places nearby Italy, Greece or Turkey) and the pictures of young children and babies

\footnotetext{
167 See supra notes 43 and 46.

168 Moreno-Lax, supra note 18, 218.

169 De Schutter, Fact Sheet No. 15, supra note 14, 5.

170 S. Fredman, Human Rights Transformed: Positive Rights and Positive Duties (Oxford University Press, Oxford, 2008) 76.
} 
who drowned because their parents decided it was worthy to take a risk to offer them a safe place where they can live in peace and dignity convince us that rescuing migrants on the high seas shall be a priority over other needs and preoccupations our societies have. States have an extraterritorial duty to protect, and its realisation cannot but be a priority over other duties they may have. The duty to protect needs to be balanced against the general interest (including national security) and the rights and interests of other individuals and social groups. The duty is susceptible to limitations, the primary one - which in a sense is inherent to it - being that it corresponds to an obligation of means and not of result. But, the starting point of legal reasoning should be that a legal duty exists in positive international (human rights) law to save/protect human life at sea. That duty extends beyond the borders of the state and has an extraterritorial reach that (it is our opinion) extends to the high seas even when a state is not linked with the situation through nationality or any other traditional link/basis for the establishment of jurisdiction. The existence of effective links between a state and a situation calling for the protection of the most fundamental rights that are associated with the basic values of humanity activate the duty to protect in light of the principle of due diligence. The involvement of states needs to be assessed on a case-by-case basis, taking into account what links them to a particular situation that requires protection. Once the duty to protect has been established, a number of other factors relevant to state fault need to be considered, such as knowledge and ability to act. Finally, because of the transnational nature of migration, more than one nation is involved and needs to demonstrate diligence with a view to prevent or remedy the sufferings of individuals. This implies a situation of parallel, overlapping jurisdiction exercised by multiple states-duty bearers. This may lead to concurrent liability and, mainly, makes clear that migration requires collective action and co-operation between nations. ${ }^{171}$ United we stand, divided we fall ...

171 As we argued in Section 1 of the study, such a legal duty may also stem from treaties outside human rights. On the duty to co-operate, see Article 7 Protocol against the Smuggling of Migrants by Land, Sea and Air Supplementing the United Nations Convention against Transnational Organized Crime, supra note 28. See also Unsc Res. 2240, supra note 9, in which the Security Council "[e]xpress[es] ... strong support to the States in the region affected by the smuggling of migrants and human trafficking, and emphasiz[es] the need to step up coordination of efforts in order to strengthen an effective multidimensional response to these common challenges in the spirit of international solidarity and shared responsibility, to tackle their root causes and to prevent people from being exploited by migrant smugglers and human traffickers" (preamble). According to the Security Council, that task "requires a coordinated, multidimensional approach with States of origin, of transit, and of destination". Finally, see supra note 160. 